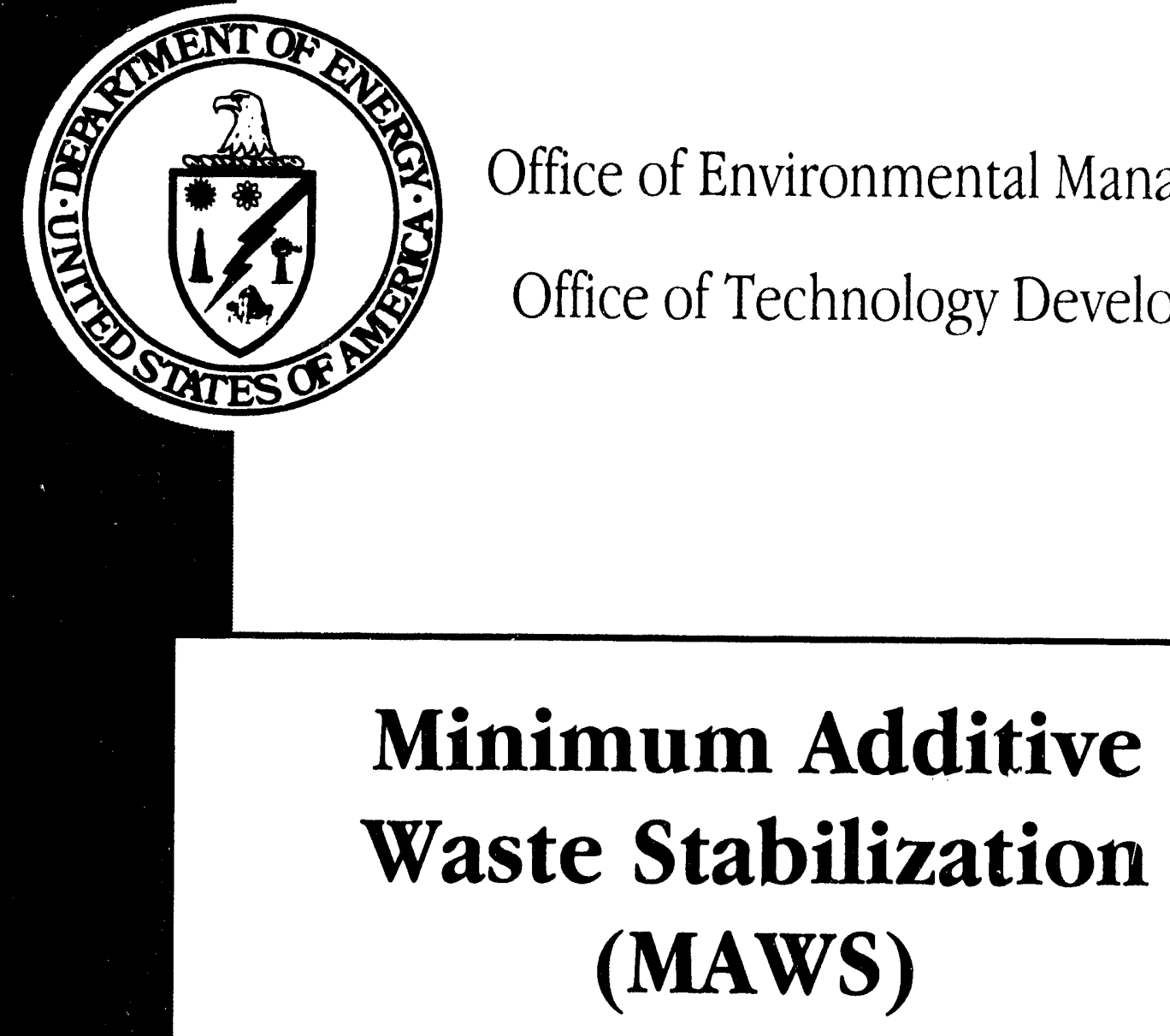

\title{
Technology Summary
}

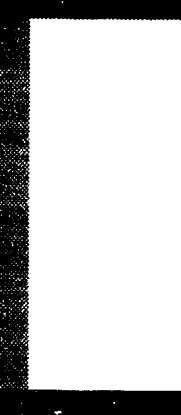

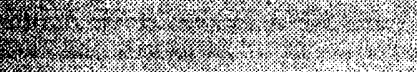




\section{MINIMUM ADDITIVE WASTE STABILIZATION}

TABLE OF CONTENTS

Page

OFFICE OF TECHNOLOGY DEVELOPMENT PREFACE iii

MINIMUM ADDITIVE WASTE STABILIZATION OVERVIEW ............................

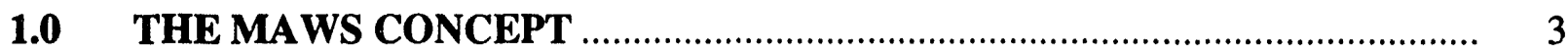

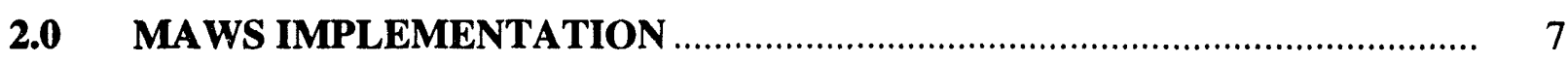

$2.1 \quad$ Window of Opportunity ........................................................................ 9

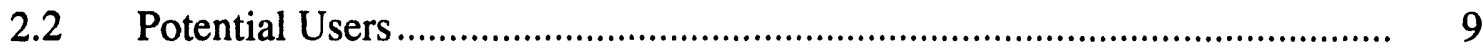

2.3 University/Industry Partners ................................................................. 11

$2.4 \quad$ Regulatory/Public Acceptance …………….............................................. 11

2.5 Environment, Safety and Health ......................................................... 12

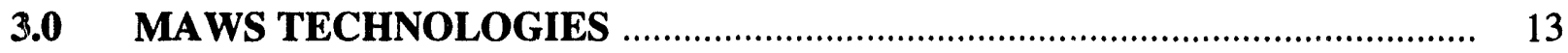

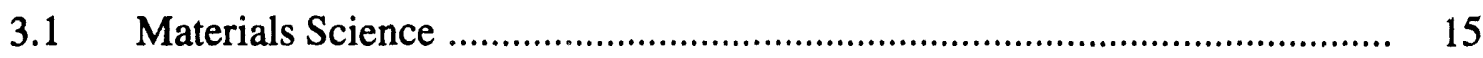

3.2 Equipment Development/Demonstration ............................................... 19

3.3 Waste Form Durability/Characterization ................................................... 23

3.4 Life Cycle Savings/Benefits ................................................................. 25

4.0 MAWS APPLICATION AT FERNALD ………....................................... 27

$4.1 \quad$ Specific Technologies ..................................................................... 31

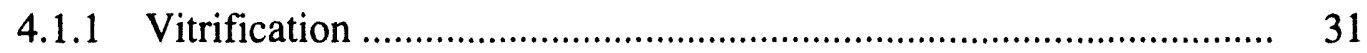

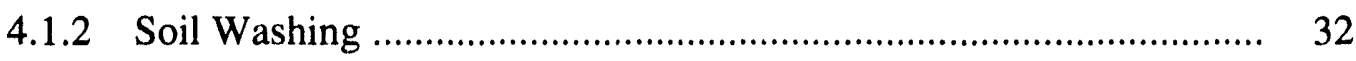

4.1.3 Water Treatment ................................................................. 33 


\section{MINIMUM ADDITIVE WASTE STABILIZATION}

\section{TABLE OF CONTENTS (Continued)}

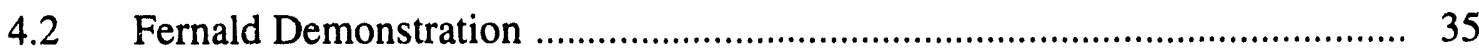

4.2.1 Phase I - Lab Development .................................................. 35

4.2.2 Phase II - Site Demonstration ............................................. 37

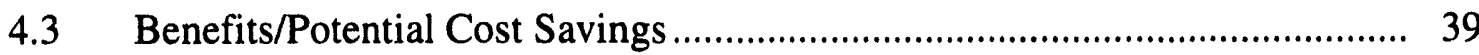

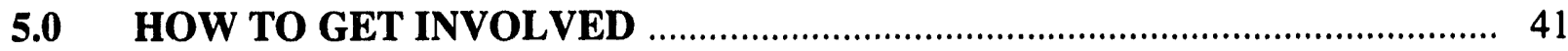

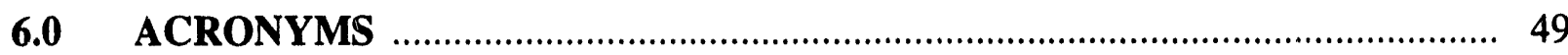

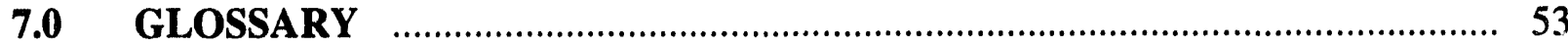

APPENDIX A - Letter Report - Minimum Additive Waste Stabilization (MAWS)

Technology - Scoping Cost Savings Analysis ............................................................... Al

\section{FIGURES}

1. U.S. Department of Energy Organizational Structure as of June $1993 \ldots \ldots \ldots \ldots \ldots \ldots . . . \quad v$

2. Office of Technology Development Organizational Structure as of June 1993 ........ vi

3. Minimum Additive Waste Stabilization Concept .......................................... 6

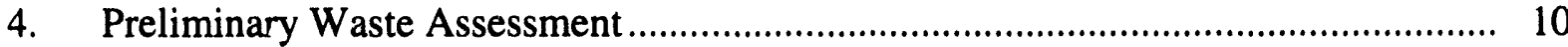

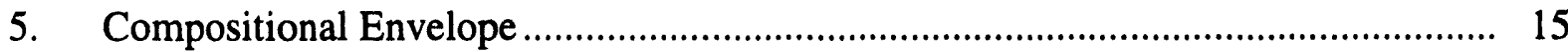

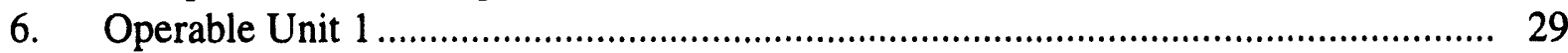

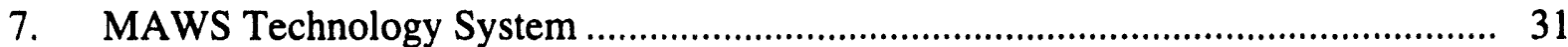

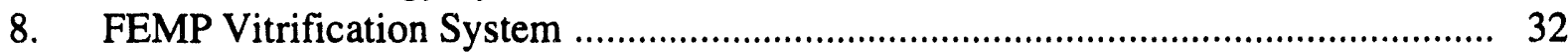

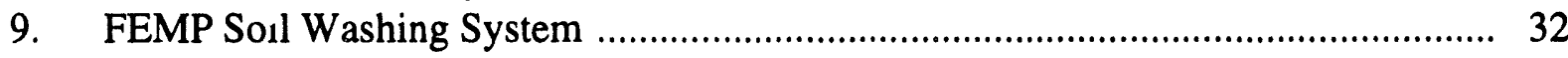

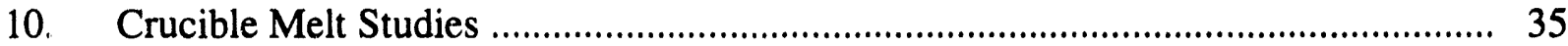

11. Enhanced Volume Reduction ....................................................................... 39

12. Benefits of Volume Reduction at Fernald ..................................................... 39

\section{TABLE}

1. Research Opportunity Announcement and Implementation Phases 


\section{OFFICE OF TECHNOLOGY DEVELOPMENT}

\section{PREFACE}

The Department of Energy (DOE) established the Office of Technology Development (EM-50) as an element of the Office of Environmental Restoration and Waste Management (EM) in November, 1989 (see Figure 1). EM manages remediation of all DOE sites as well as wastes from current operations. The goal of the EM program is to minimize risks to human health, safety and the environment, and to bring all DOE sites into compliance with Federal, state, and local regulations by 2019. The Office of Technology Development is charged with developing new technologies that are safer, faster, more effective and less expensive than current methods. The organizational structure of the Office of Technology Development is shown in Figure 2. The Minimum Additive Waste Stabilization Program (MAWS) is part of EM-541, the Environmental Restoration Research and Development Division of EM-54.

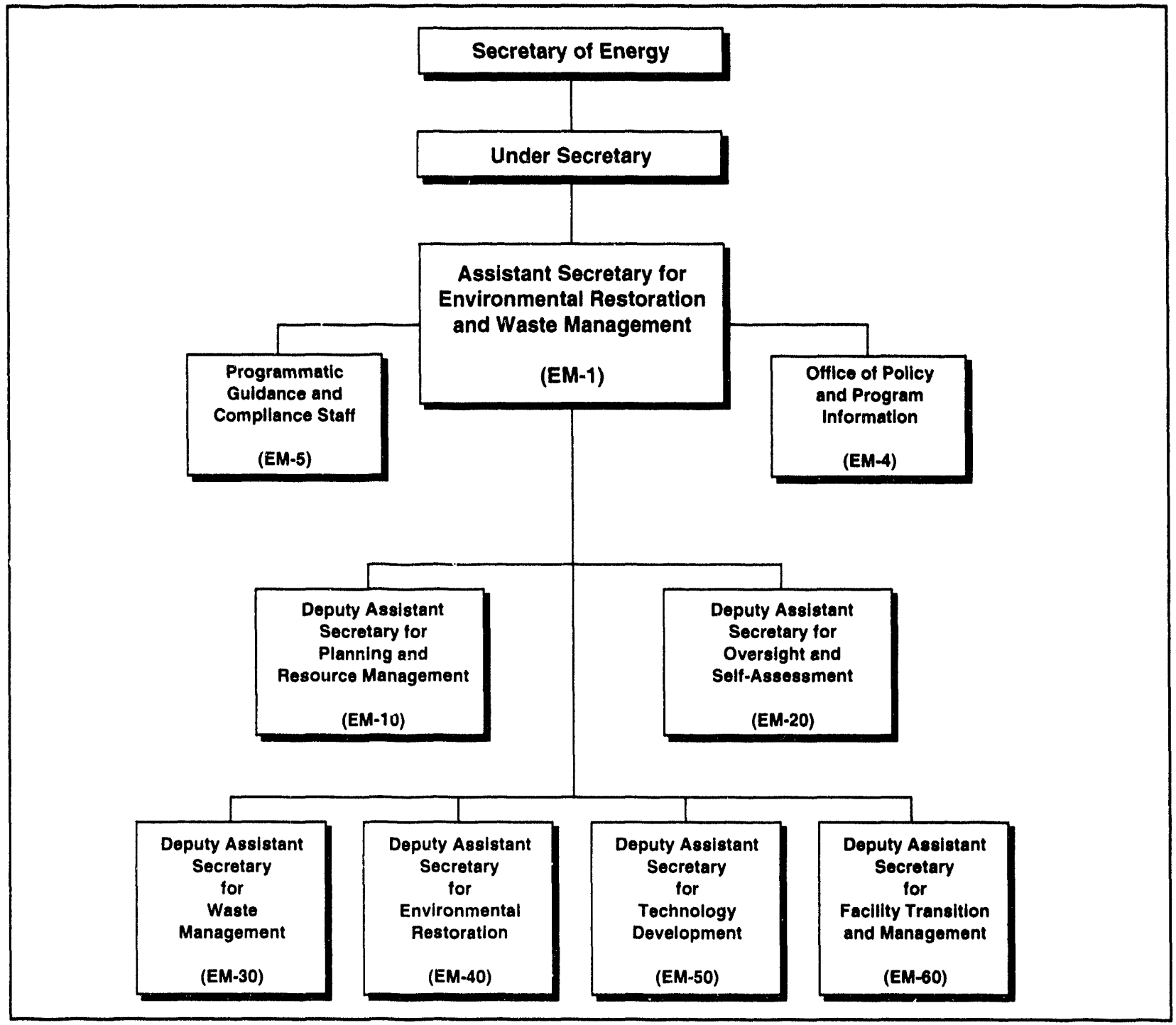

Figure 1. U.S. Department of Energy Organizational Structure as of June 1993. 


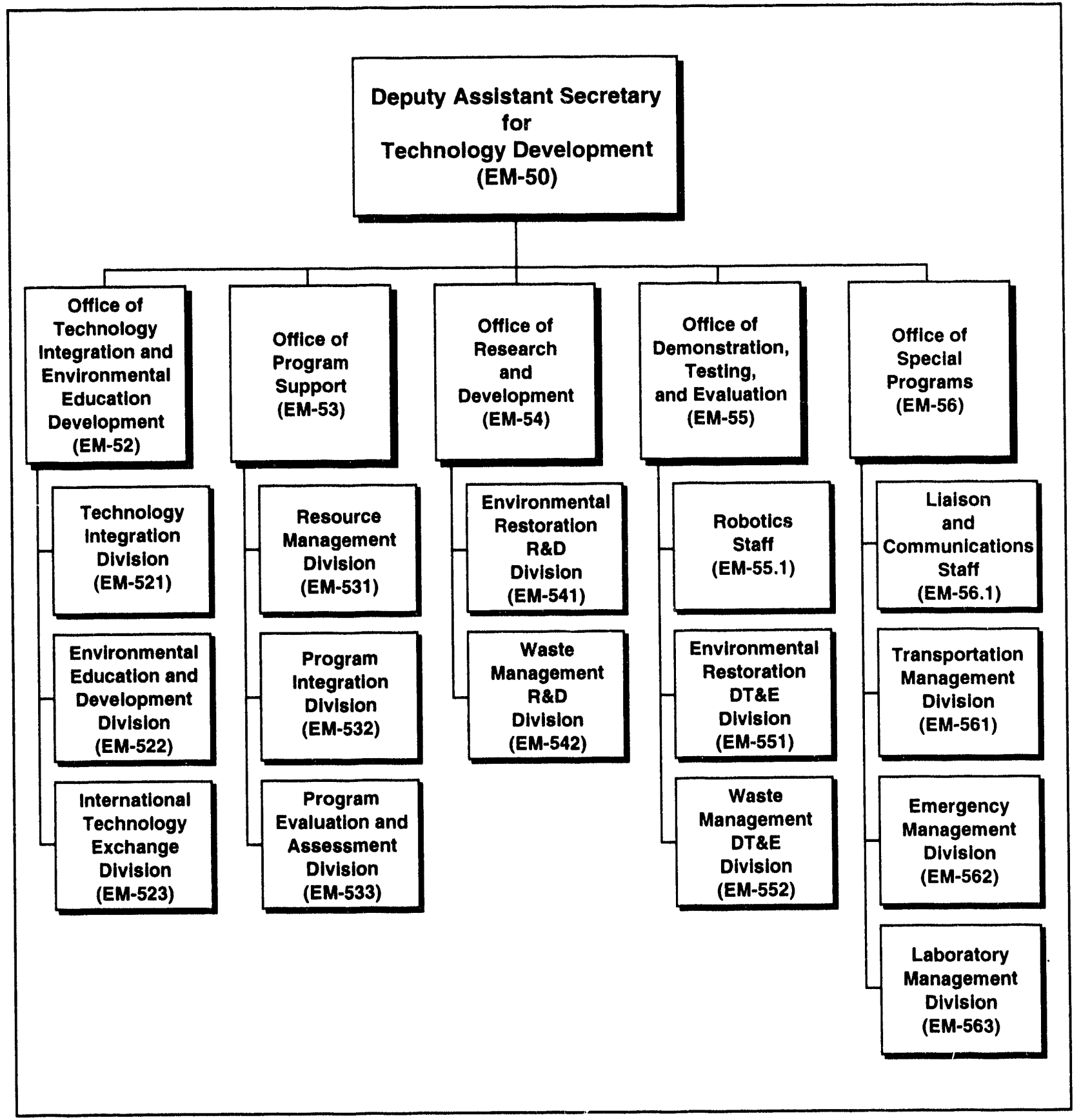

Figure 2. Office of Technology Development Organizational Structure as of June 1993. 


\section{MINIMUM ADDITIVE WASTE STABILIZATION}

\section{OVERVIEW}

DOE has a large number of sites that are listed on the National Priority List (NPR). These sites have tank wastes, sludge pits, evaporation ponds, injection wells, rubble pits, etc. contaminated with hazardous constituents and radioactivity that require remediation. The associated large amounts of contaminated soil and groundwater in the surrounding area and other miscellaneous waste streams (fly ash, asbestos, transite, resins) also need to be remediated. Cementation of these waste streams has shown to be largely ineffective over the long term. Vitrification is a technically sound alternative to cementation. However, the quantity of these waste streams is so high that the conventional high level waste vitrification approach would be very expensive.

A new cost effective approach to vitrification is Minimum Additive Waste Stabilization (MAWS), which provides an environmentally sound alternative for the vast amount of low level radioactive/ mixed waste that exists within the DOE complex. MAWS utilizes multiple waste streams as substitutes for additives otherwise necessary for vitrification to produce a stable, high quality waste form. MAWS results in the minimum waste volume for disposal.

The objective of the MAWS program is to develop technology systems to effectively remediate a large quantity of multiple waste streams in a cost effective manner. The first pilot scale demonstration and evaluation of the MAWS technical system will be implemented at Fernald, Ohio. As discussed further in Section 4.0, the cost savings of remediating one single Operable Unit (OU) at Fernald is projected to be a minimum of $\$ 100 \mathrm{M}$, which will be verified once the demonstration is completed. The emphasis in and beyond FY94 will be focused on application to other DOE sites, such as Hanford, Oak Ridge, INEL, etc. Consequently, additional MAWS technology/systems will also be developed as required by the treatment needs of the different types of waste streams investigated. So far, the current program involves participants from Fernald Environmental Management Project (FEMP), private industries, academia, and National Laboratories.

For more information on the MAWS Program, please contact:

Ms. Grace Ordaz

Office of Technology Development

U.S. Department of Energy

12800 Middlebrook Road

Germantown, Maryland 20874

(301) 903-7440 
In the MAWS concept, actual waste streams are utilized as additive resources for vitrification, which may contain the basic components (glass formers and fluxes) for making a suitable glass or glassy slag. If too much glass former is present, then the melt viscosity or temperature will be too high for processing; while if there is too much flux, then the durability may suffer. Therefore, there are optimum combinations of these two important classes of constituents depending on the criteria required. The challenge is to combine these resources in such a way that minimizes the use of non-waste additives yet yields a processable and durable final waste form for disposal. The benefit to this approach is that the volume of the final waste form is minimized (waste loading maximized) since little or no additives are used and vitrification itself results in volume reduction through evaporation of water, combustion of organics, and compaction of the solids into a non-porous glass. This implies a significant reduction in disposal costs due to volume reduction alone, and minimizes future risks/costs due to the long term durability and leach resistance of glass.

This is accomplished by using integrated systems that are both cost-effective and produce an environmentally sound waste form for disposal. Individual component technologies may include:

- vitrification;

- thermal destruction;

- soil washing;

- gas scrubbing/filtration; and,

- ion-exchange wastewater treatment.

The particular combination of technologies will depend on the waste streams to be treated. At the heart of MAWS is vitrification technology, which incorporates all primary and secondary waste streams into a final, long-term, stabilized glass waste form. The integrated technology approach, and view of waste streams as resources, is innovative yet practical to cost effectively treat a broad range of DOE mixed and low-level wastes.

Vitrification has traditionally been used within the DOE Complex for treatment of low-volume, high-level radioactive wastes with low waste loading and high treatment cost. However, the economic attractiveness for treating large volumes of low-level/mixed waste (by maximizing waste loading) and the feasibility of production-scale processing have yet to be demonstrated. This program will demonstrate both the economics of total life-cycle cost savings, through increased waste loading and final waste volume reduction, and the production-scale feasibility of various vitrification technologies to treat large volumes of low-level/mixed waste through a synergistic approach. In addition, it will demonstrate the capability of producing a leach-resistant (long-term) waste form, with byproducts such as clean water and soil for placement back into the environment, and an off-gas effluent that meets regulatory requirements (See Figure 3).

The vitrification process uses high temperatures (typically between 1100 and $3000^{\circ} \mathrm{C}$ ) to chemically incorporate wastes into a glasseous matrix. Vitrification is a process whereby a material is transformed at high temperatures into an amorphous liquid, which upon cooling and largely without crystallization becomes an amorphous solid. Crystalline phases may be either thermodynamically unstable or kinetically unable to form during the cooling down period. Either way, the resulting bulk solid has an unordered structure. A glass by definition is a completely amorphous solid, whereas a ceramic is largely crystalline with fused grain surfaces. 
In between these two extremes are a wide variety of glassy ceramics in which crystalline phases are dispersed throughout a glassy continuous phase. Such materials may include slags which incorporate various metal oxides. These waste forms are also under evaluation, and show promise for long term stability and leach resistance.

Glass or glassy ceramic (slag) waste forms produced by vitrification are unique in that they can easily accommodate a wide range of metal oxides into their structure and yet produce a stable and durable material. It is precisely the amorphous structure of the glass phase which allows this incorporation of many constituents, and why vitrification was chosen as the technology upon which MAWS is based. The waste is not merely encapsulated, but actually becomes part of the glass structure.

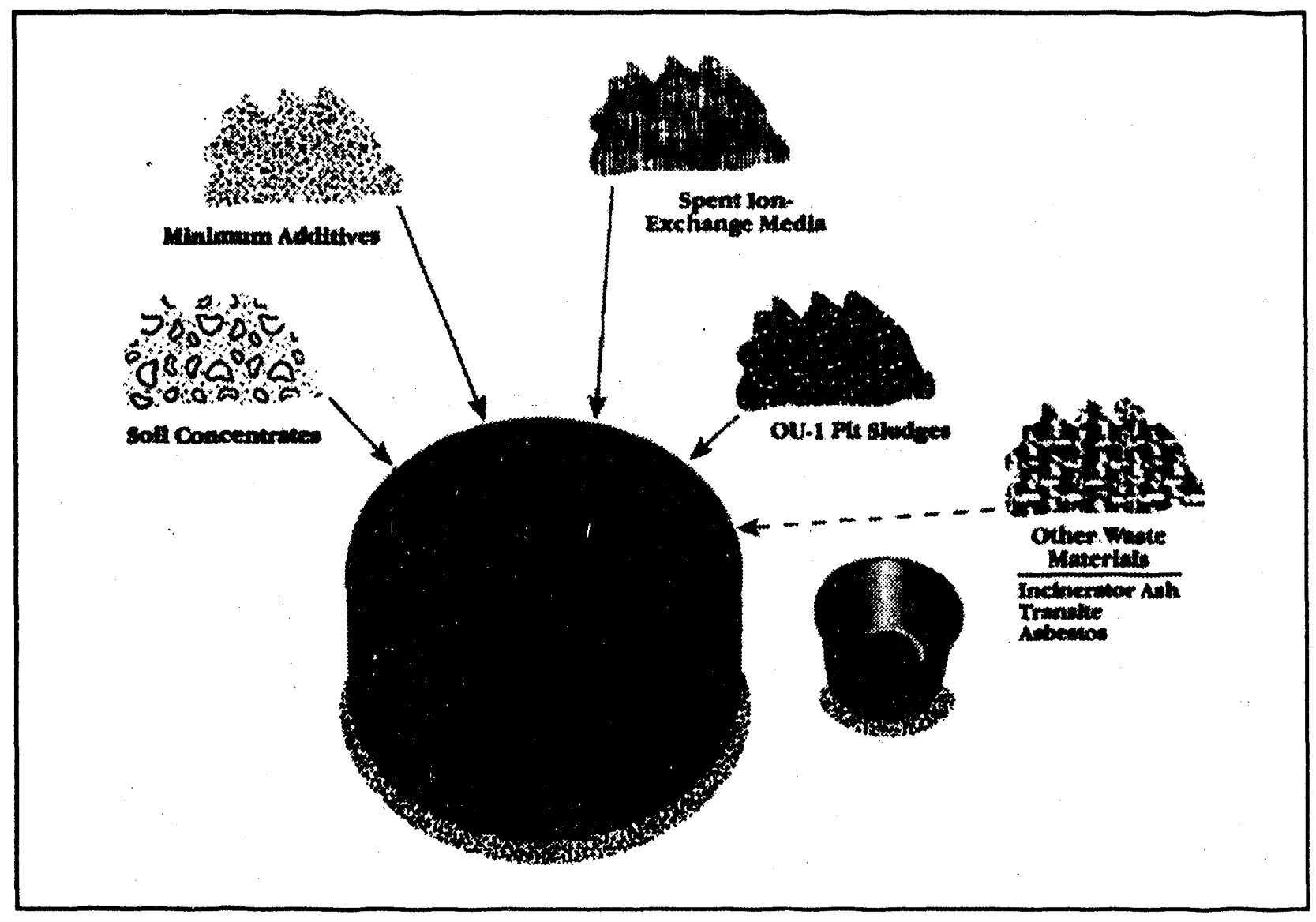

Figure 3. MAWS Concept. 
For the DOE complex, the window of opportunity for technology selection to treat the various wastes is estimated to be 1992 to 1999 for Waste Management, and from the present to beyond the year 2000 for Environmental Restoration. Specific needs will be determined by the individual sites to support Record Of Decision (ROD) dates. Prioritization of sites according to ROD dates and cleanup urgency will be necessary for optimum efficiency and program focus. For the first test of MAWS at the Fernald OU-1 Demonstration, the window of opportunity is FY 92-94 with a ROD date of December 1994. The start of test operations in October 1993 should provide needed data for further scale up decisions to address this ROD date.

\subsection{Potential Users}

The Office of Environmental Restoration is identified as the primary user of the MAWS program. The pit wastes, contaminated soils and groundwater, and other waste materials that are present at the many environmental restoration sites are ideal for the MAWS systematic approach where the various wastes are used to complement each other during treatment, and are treated in one closed loop system to maximize cost savings. The MAWS concept can and should be applicable on a broad scale. Also, many of the other OTD programs that address Waste Management's wastes (e.g. Mixed Waste Integrated Program, Efficient Separations Integrated Program, and Underground Storage Tanks Integrated Demonstration, etc.) can benefit from the results generated by the MAWS program.

The MAWS concept (waste as resources and integrated technologies) is expected to be applicable complex-wide where remediation needs are evident. Preliminary surveys have indicated such sites as Hanford, Savannah River, Rocky Flats, and Oak Ridge, as well as additional Fernald Operable Units (which have CERCLA commitments for which no specific treatments have been yet identified) as potential candidates (see Figure 4). Indeed, there is growing interest in the MAWS concept due to: 1) waste minimization, 2) reduced costs, and 3 ) the stable nature of glass waste forms. Vitrification is the center of the MAWS technology, and is applicable and appropriate for a large quantity of DOE wastes such as soils, tank wastes, sludge pits, ashes, asbestos, transite, and others. See Figure 4 for some examples.

\section{Fernald}

Phase I and II results from Fernald will be used for input to the OU-1 ROD which is due 12/94. There are several , ther pits within OU-1, and even otheroperable units that are presently under consideration for extension of MAWS applicability. Once the initial demonstration is completed, these other applicable wastes can be considered as to optimum compositional mixtures and processing conditions to best utilize similar technology.

\section{Hanford}

Treatment alternatives for the high-level tank wastes at the Hanford site are presently under review. The process selected will most likely involve separation of the wastes into a high activity stream and lower activity side stream with vitrification of the former. However, treatment methods for the large-volume lower activity stream are less certain. Simple vitrification of these low activity wastes with 


\section{Preliminary Waste Assessment for MAWS Applicability}

Site

Hanford

Rocky Flats

Oak Ridge

Savannah River

Fernald

\section{Waste Stream Amicable to MAWS}

soils, sludges, groundwater, buried waste*

soils, sludges, groundwater, pondcrete, saltcrete

soils, sludges, ground and surface water, ash and debris (from burn pit)* asbestos, buried waste*

soils, sludges (basins), groundwater, ash and debris (burn pits)* construction debris w/metal, LLW disposal facility*

soils, sludges (pit), groundwater, transite, asbestos, sanitary landfill*, fly ash

* debris and buried wastes include one or more of the following: metals, plastic, cement, ash, liquids, glass, and other laboratory equipment, etc.

NOTE: This is a preliminary assessment that is not all-inclusive of the site remediation problem. Information is taken from GeoTech Reports and FFCA data being compiled. Level of detail available for each varies.

Figure 4. Preliminary Waste Assessment for MAWS Applicability.

additives would be more costly than cementation due to the low waste loading typically employed, while cementation would likely produce an inferior final waste form.

From a MAWS perspective, a separated low activity waste stream from this high-level defense waste would be a valuable commodity, since it is composed predominantly of sodium salts which are effective fluxing agents. In addition, Hanford has very large volumes of contaminated soils (about 22 million $\mathrm{yd}^{3}$ in the 100 and 300 areas alone) which will likely require volume reduction by soil washing with the contaminant enriched stream requiring stabilization. In the MAWS approach, these two streams can be combined to produce a vitrifiable blend, and thereby realize substantial cost savings over treating these two waste streams separately.

\section{Oak Ridge}

For Oak Ridge, the MAWS concepts have been applied at the lab and bench scale to a waste stream generated at the $\mathrm{Y}-12$ facility. Approximately 500,000 tons of a Y-12 storm sewer sediment that is contaminated with mercury, uranium, thorium, and PCBs is now in storage at the K-25 facility. As a result of the lab and bench scale studies, a multiple-technology integrated treatment system is conceptualized to treat these wastes. The process would combine size separation, thermal desorption, soil washing, ion exchange, and vitrification to produce clean soil, a non-radioactive pure mercury stream, and a highly leach resistant, volume reduced, glass waste form. The estimated processing cost for the system is about $\$ 260-\$ 420 / y d^{3}$. Other Oak Ridge wastes that are presently under study at 
the lab scale include Toxic Substances Control Act (TSCA) incinerator ashes, ionizing wet scrubber sludges, and $\mathrm{K}-25$ and $\mathrm{Y}-12$ waste water treatment sludges. These investigations will provide the data that are necessary to evaluate the potential application of MAWS technology to these streams, either individually or in combination.

\section{Rocky Flats}

Process sludges from the Rocky Flats Plant have previously been treated by cementation, but have produced a largely unacceptable waste form known as "Pondcrete"; this material will likely require further treatment. Other process sludges were directed to Solar Ponds for evaporation and these wastes also require stabilization. As is commonplace at most DOE sites, there are large amounts of siliceous waste streams such as contaminated soils, transite, asbestos, etc. These materials would be useful ingredients for blending with Solar Pond wastes which are high in fluxing agents using a MAWS approach. Evaluation of this concept based on presently available Solar Pond waste characterization data is in progress and discussions with Rocky Flats Plant personnel have been initiated.

\section{Weldon Spring}

Application of vitrification to raffinate pit wastes (about 200,000 $\mathrm{yd}^{3}$ ) stored at the Weldon Spring site in a MAWS blended waste stream approach using contaminated site soils has been demonstrated in laboratory studies. High waste loading, highly leach resistant glass waste forms have been produced which could result in large volume reduction, as compared to a volume increase on cementation. Consequently, lifecycle cost analyses show very large potential cost savings using the MAWS approach for any realistic unit volume disposal cost.

\subsection{University/Industry Partners}

A nationally and internationally recognized waste vitrification and glass waste form development, testing, and characterization program has been established at VSL over many years. A large fraction of this success has been due directly to DOE interest and support. As a result, this facility now provides a valuable resource for DOE research, development, demonstration, and testing activities. This is especially true in view of the close collaboration of VSL with GTS Duratek which provides the opportunity for unusually rapid scale-up, technology transfer, and commercialization. Current and anticipated future MAWS funding will significantly enhance the capabilities at VSL for supporting DOE technology development and site-remediation activities. VSL and GTS Duratek joule heated melter vitrification studies have provided invaluable support for many DOE sites, including West Valley, Savannah River, Weldon Spring, Fernald, and Oak Ridge.

In addition, high temperature vitrification evaluations are being carried out by MSE, Inc. in Butte, MT in conjunction with Retech in Ukiah, $\mathrm{CA}$, and soil washing capabilities are provided by Lockheed Environmental Services Corp. in Las Vegas, NV. The MAWS program seeks to develop and integrate the best technologies to meet the challenges of the varied DOE waste problems. Therefore private industry and university participation is a key contributor to this effort.

\subsection{Regulatory/Public Acceptance}

The plans for the Fernald demonstration of the MAWS technology using vitrification, soil washing, and ion exchange water treatment have gone through the CERCLA remediation process, received Ohio Regulatory Agency approval, and have been given full public support by local 
stakeholders such as Fernald Residents for Environmental Safety and Health (FRESH). Any future plans for demonstration of the MAWS technology will also seek input and acceptance from all stakeholders and involved agencies.

Also the MAWS demonstration at Fernald is seeking to meet guidelines set out in the Superfund Innovative Technology Evaluation (SITE) program.

\subsection{Environment, Safety and Health}

The task-specific Health and Safety plan for Fernald operations was prepared as a supplement to the formal site-wide Health and Safety Plan for the FEMP site. Personnel from Westinghouse
Environmental Management Company of Ohio (WEMCO) and GTS Duratek will follow this Health and Safety Plan while conducting the pilot-scale treatability study operational tasks as described in Section 4.0. The contents of the task-specific Health and Safety Plan are consistent with Title 29 Code of Federal Regulation (CFR) 1910.120, Hazardous Waste Operations and Emergency Response and the FEMP Site Health and Safety Plan (June 1990). In general, Management and Operating (M\&O)/ Environmental Restoration Management Contractors (ERMC) and non-M\&O/ERMC subcontractors working on this project at DOE facilities operate under the directives contained in the DOE order series 5480, and are required to follow specific directives under DOE order 5480.19 . 


\subsection{MAWS TECHNOLOGIES}

For the MAWS concept to grow in acceptability and have maximum flexibility for application across the spectrum of wastes at the various DOE sites, it is necessary to expand the compositional envelope and prove the leach resistance/durability of resulting waste forms. Also, the compositional envelope needs to be tied to specific melter and associated support technologies, i.e. the equipment technology should fit the waste stream, rather than vice versa, to insure that minimum additives are used in making the glass waste form. This all has to be done in a safe, cost effective, and environmentally sound manner.

Therefore, for effective implementation of the MAWS concept, developmental work must proceed in several areas including materials science, equipment development, waste form durability/characterization, and life cycle savings/benefits. Several current Technical Task Plans address the needs in each of these areas. 


\section{TASK DESCRIPTION}

The first step in considering whether a MAWS approach will work for a particular set of waste streams is to characterize the wastes and the various glasses made from combinations of them. This may involve significant resources in the extensive testing required to insure that the glass is stable, durable, and processable. Materials science is an integral part of this process. Obviously, if the assessment of new waste streams can build from the knowledge gained during earlier ones, then this process can proceed more quickly. That is the main objective of this task.

To date two distinct regions of the compositional envelope have been identified as having the potential to yield environmentally sound final waste forms (see Figure 5).

These are a pure glass region which is more amenable to lower temperature melter equipment, and a glassy slag region which is better suited to high temperature processing. The glassy region contains mostly "structure making" components and "fluxes" with small to moderate amounts of intermediates or crystal formers. This work is being performed at Catholic University. The slag region also contains "structure making" components and higher quantities of intermediates (oxidized metals) with minimal fluxing agents. This work is being performed at Argonne National Laboratory. Whereas the glass is completely amorphous, the glassy slag may contain crystalline or ceramic components which are also very durable. Both waste forms are being developed in order to address the widest spectrum of DOE wastes.

Most of the waste streams considered to this point, such as sludges and soils, require melting at low temperatures to minimize the complexity of the off-gas system. For these systems a low-temperature jouleheated melter like the one planned for Fernald is ideal, however there are other waste streams

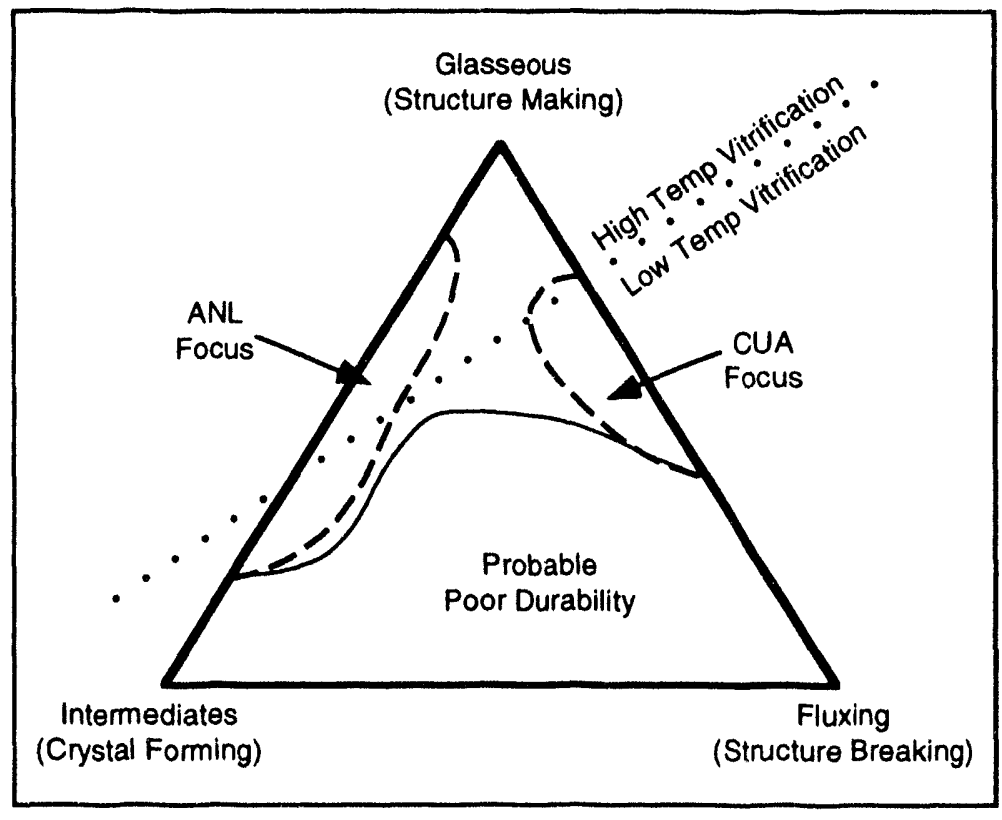

Figure 5. MAWS Compositional Envelope. with high metal contents, high organics, or insufficient fluxes for which this technology is not acceptable. Therefore additional technology development is required, both in the area of melter equipment and in extending the compositional envelope to these other regions. This will insure that a quality, stable, final vitrified waste form can be generated with minimum additives.

In order to focus on real problems, actual wastes from the DOE complex will be the focus of development studies where possible to shorten the time frame to commercialization. DOE waste stream data will be 
reviewed, and major types of waste streams selected for study that would greatly expand the present compositional envelope, and allow application of the MAWS technology to other DOE sites. These waste streams should be located towards the boundaries of the current MAWS system "acceptance window", and in such a way that the greatest possible fraction of DOE waste streams are encompassed. The MAWS technology system here is defined as technologies that will be able to treat major types of wastes that exist within the DOE, and are not limited to the technologies currently under investigation. The waste streams will be selected relative to a prioritized window of opportunity using Record of Decision dates as the starting point.

The specific tasks will include:

- Conduct characterization of waste streams for glass making purposes.

- Conduct crucible melt studies and collect associated glass characterization data to identify the optimum formulation or waste blend with respect to overall economics (volume reduction, waste loading, additive requirement), processing requirements (viscosity, conductivity, crystallization) where necessary, and waste form performance (long-term leach resistance).

- Continue the effort of correlating existing waste and glass data (literature, related simple systems, previous studies on similar wastes, experience from glass material science) to new waste streams.

- Expand previously developed Fernald waste models with data developed from other pit wastes at Fernald, and also incorporate other sites into this work.
- Compare crucible melt samples to those produced in bench scale or larger equipment to improve development techniques. Provide optimized waste stream blending guidance for bench scale tests to prove chosen melter techniques.

\section{TECHNOLOGY NEEDS}

Most DOE sites have a large variety of predominately inorganic waste streams (e.g. sludges, incinerator ash, contaminated soils/ water, and transite/asbestos). The MAWS concept is applicable to these wastes, and has potential for significant cost savings during remediation and treatment. The objective of this task is to provide information and data to guide, focus, and expedite development studies required for new waste streams, reduce overall development costs, and reduce cycle time from waste characterization to technology implementation. This would permit identification of optimal formulations and a rapid evaluation of the applicability and potential benefits of the MAWS technology for any given remediation problem. Development of compositional information for the waste streams and desired final form is the important first step in the process to apply MAWS.

\section{ACCOMPLISHMENTS}

- Characterization and crucible melts of FEMP wastes (sludges, soil concentrates, and fly ash) have achieved up to $93 \%$ waste loading while producing quality glass. Extensive data on composition provides a solid foundation for incorporation of other new waste streams.

- In glassy slags up to $74 \%$ waste metal loading combined with contaminated soil 
and zero purchased additives has been demonstrated.

- Crucible melt studies are continuing to expand the compositional envelope with new waste streams.

- Waste streams from several sites are being identified, prioritized, and characterized. Interest in the MAWS concept to treat these wastes is being investigated.

- The Structural Bond Strength model has been shown to be very promising in optimizing glass formulations. Relative computed stabilities agree with measured durabilities.

- Crucible melt studies have yielded stable, durable glass and slag final waste forms capable of passing TCLP and PCT tests.

COLLABORATION/TECHNOLOGY TRANSFER

GTS Duratek and Vitreous State Laboratory (VSL) of Catholic University of America (CUA) have established a working relationship to develop the glass portion of the compositional envelope which will build off of the Fernald development. Argonne National Laboratory is providing contractual, management support, and is conducting long-term durability glass testing, as well as developing the glassy slag portion of the compositional envelope dealing with high temperature/low flux waste streams.

For further information, please contact:

\section{Dr. Ian Pegg}

Principal Investigator

Catholic University of America, VSL (202) 319-6700

\section{Dr. Xiangdong Feng}

Principal Investigator

Argonne National Laboratory

(708) 252-7362 


\section{TASK DESCRIPTION}

The focus of this study area is on the vitrification and associated supporting equipment to be to used in the MAWS concept, with a view toward the feasibility of producing an environmentallysound and durable final waste form. The objective is to assess the current state of vitrification technology and choose those technologies for further radioactive waste treatment development that have a proven record of accomplishment, reliability, and commercialization in the private sector. Once these assessments have been completed, a long range plan needs to be developed that will provide costs and strategies to bring these technologies on-line for radioactive waste treatment. It is initially envisioned to assess two technologies at the bench scale, and then choose one for initial further development at the pilot stage. A plasma technology has been identified as one likely melter configuration which is now being assessed at the bench scale.

The comprehensive plan to implement/ coordinate additional MAWS developmental work needed for equipment evaluation will be prepared and completed by early October 1993. This plan is being prepared by MSE, Inc. with guidance from DOE. MSE is identifying potential entities (industries academia, and the National Laboratories) for their specific expertise to conduct work in the following technology areas:

- Materials science studies to determine the matrix of test materials.

- Identification and assessment of promising technologies as to MAWS applicability, their maturity stage, and availability of equipment for testing. This includes recommendation of a few of the most promising for further development.
- Identification of testing facilities ( $\mathrm{rad} / \mathrm{non}$ rad) for capabilities.

-Waste product long-term durability testing to validate the waste form quality.

- Preliminary life cycle cost estimation.

- Cost and overall schedule for the entire packaşe.

MSE will solicit input from appropriate entities to participate in various parts of the MAWS program, review their proposals, and make recommendations in the area of promising equipment to be developed. MSE will integrate the recommended proposals and propose an overall plan and schedule to initiate work in FY94.

Work to this point has focused almost entirely on a low temperature joule heated melter system. In other variations of vitrification technology, a plasma or microwave system may be employed as a high temperature process operating between 1800 to $2600^{\circ} \mathrm{C}$. In such a system a more viscous glass or slag can be produced with fewer limitations on metals content or organics in the waste streams chosen. As before, the cost effectiveness of the technology compared to other technologies will be the main driver along with production of a stable, durable final waste form.

Initial evaluation tests are currently underway using the Plasma Centrifugal Furnace (PCF) technology available from Retech, Inc. These tests are being coordinated by MSE, Inc. In these tests, metal loadings up to $70 \%$ are anticipated which will produce a durable final slag waste form. Produced wastes will be carefully evaluated by Toxicity Characteristic Leach Procedure (TCLP) and Product Consistency Test (PCT) 
determinations. In addition, off-gas data will be collected and assessed to determine the effectiveness of the technology system as a whole for treating waste and posing no further threat to the environment.

Pending the results of the bench scale testing work and the direction chosen, future development work may be required to begin the scale-up to a commercial sized vitrification system which can be incorporated into the overall MAWS concept. This future pilot stage should probably be site specific for a particular set of waste streams that can best use this technology.

\section{TECHNOLOGY NEEDS}

To compliment the compositional envelope work, several vitrification technologies need to be evaluated to be able to handle waste streams not suited to the low-temperature joule-heated melter. Much of this development work can be done concurrently with the compositional development work by using a mix of actual and simulated waste streams in test work. The real waste streams will serve to focus the efforts on real problems while the simulated waste streams will allow maximum information to be derived from compositional variation. For easy transfer to the many potential waste sites, assessments as to the maturity of the specific technology need to be done. In many cases, this may require both bench scale evaluations as well as pilot plant operations to minimize risks and potential problems when the technology becomes commercial.

It is desired to practice the MAWS concept with various technologies to fulfill a wide range of treatment needs. Technologies to compliment the current low temperature Joule heated furnace configuration are needed particularly for wastes with a high metals content. One example of such technology is the plasma centrifugal furnace which needs to be proven in its ability to completely oxidize the metals to arrive at a stable and durable waste form. The results should give an initial indication of the capability of plasma utilizing the MAWS concept.

\section{ACCOMPLISHMENTS}

- A low temperature Joule heated melter has been developed and radioactive feeds tested at the bench scale. The melter has successfully processed high fluorine wastes to produce quality glasses.

- The procurement package for Retech to do the plasma testing at Ukiah, CA has been completed. It was submitted to PETC for approval and has been issued to Retech.

- Provisions have been made for off-gas sampling during the tests to provide data on problem volatiles.

- Initial tests have indicated that the equipment is capable of melting mixed high metal containing wastes; complete metal oxidation has been achieved in a test with up to $70 \%$ carbon/stainless steel. More work is being done to optimize furnace operational parameters and explore compostional variation.

- A draft of the long range plan has been put together which identifies both single and two stage thermal treatment options and fast track versus normal development options.

\section{COLLABORATION/TECHNOLOGY TRANSFER}

Current technology development of the PCF is being coordinated through MSE, Inc. at Retech in Ukiah, CA. Laboratory evaluation of waste forms for this work is subcontracted to 
Argonne National Laboratory. The long range plan for high temperature technologies is being developed by MSE, Inc. with consideration given to conducting the test program at qualified university or industry participants.

For further information, please contact:

Mr. Dan Battleson

Principal Investigator

MSE, Inc.

(406) 494-7287

Dr. Ian Pegg

Principal Investigator

Catholic University of America

(202) 319-6700 


\section{TASK DESCRIPTION}

All glass and glassy slag forms are not equal, and therefore need to be evaluated as to their long term stability and leach resistance. Wide variation in properties can be achieved depending on the composition, and the specific tests carried out may influence the conclusions. Also, most stability and durability tests are carried out for only relatively short times in comparison to the actual time frame required for safe disposal of the materials produced. For this reason waste form durability and characterization is a major effort of the MAWS program and the main reason that glass/slag waste forms through vitrification were chosen.

An objective of the MAWS program is to provide a framework in which waste streams can be rather quickly screened, classified, and compared to the compositional envelope information already collected, but also to add to this information wherever possible to expand the acceptable regions. This involves extensive durability and leach resistance data which will be collected in a database and modeled where appropriate to reduce the effort required in subsequent searches for an acceptable mix of components. Feeding into this database will be not only compositional data, but also data from tests such as TCLP, PCT, and vapor phase tests. These provide both short and intermediate range results which can be projected to long term scenarios. Specifically the PCT tests may be carried out over $7,28,91,180$, and up to 730 day time periods. Such tests carried out at $90 \%$ relative humidity and $90^{\circ} \mathrm{C}$ provide an accelerated weathering environment in which new phases may form or surface reactions can occur to alter the stability of the glass/slag waste form.

\section{TECHNOLOGY NEEDS}

Once the MAWS concept proves to be technically feasible and economical for a particular set of waste streams, further testing is needed to demonstrate that the vitrified waste product will endure with time and will be protective of the environment. Within the MAWS concept, extensive testing is included to provide a database of the quality, consistency, homogeneity, leachability, and durability of the vitrified waste product. Expected long-term performance of the glass will be determined and documented. These data may then be used to supplement the existing database on glass performance (mainly high-level waste glass) for use in studies to determine whether it is possible to place the treated waste in less expensive disposal facilities (possible delisting), thus further reducing site remediation costs.

A three-tiered leach testing approach for durability will be used:

- Standard toxicity characteristic leaching procedure (TCLP) and product consistency testing (PCT) for leachable inorganics;

- Service condition testing; and

- Accelerated testing (vapor test) for surface reactions leading to crystal phase formation.

This tiered approach will identify and provide for practical testing methods that can be used to determine the performance of the vitrified product (including elemental and radionuclide release characteristics) under disposal conditions. A variety of other leach testing methods will also be used in conjunction with detailed surface analyses by analytical electron microscopy, 
scanning electron microscopy, secondary ion mass spectrometry, and optical microscopy. The objective of these tests will be to establish a meaningful testing approach and database for demonstrating the durability of the glass product.

\section{ACCOMPLISHMENTS}

- Two regions of relative durability/stability have been identified. The first is a true glass capable of incorporating high flux and fluoride levels, but low metals. The second is a slag form capable of incorporating high metals as oxides, but low fluxes.

- Glasses and slags have been produced that pass TCLP tests, and have PCT and vapor test results equal to or better than Savannah River high-level waste glass standards.

COLLABORATION/TECHNOLOGY TRANSFER

This work is being carried out by the Vitreous State Laboratory (VSL) of Catholic University of America (CUA) for glass waste forms and by
Argonne National Laboratories (ANL) for glassy slag waste forms. Compositional model development coordination between both facilities is in progress.

For further information, please contact:

\section{Dr. Ian Pegg}

Principal Investigator

Catholic University of America, VSL

(202) $319-6700$

Dr. James Mazer

Principal Investigator

Argonne National Laboratory

(708) 252-9798

\section{Dr. Xiangdong Feng}

Principal Investigator

Argonne National Laboratory

(708) 252-7362 


\section{TASK DESCRIPTION}

There exist many levels of technology evaluation where decisions are made for the allocation of limited research and development (R\&D) funds. Each evaluation's objective is to select for development or adaptation those technologies that are most likely to be significantly "better, safer, faster, and cheaper," which are the adjectives that summarize the goals of OTD. An important factor in these evaluations is technology cost which includes both the cost of development and the expected cost of actually using the technology in the field, i.e., the implementation/operating cost. Only when the technology is actually demonstrated in the field do costs become clearer. Even then, the implementation costs of the final, commercialized technology may be significantly lower than the demonstration costs. Uncertainty in the areas of performance, cost, regulatory approval, and schedule also plays a major role in technology evaluation. Clearly, the evaluation process of new technologies is not trivial.

Several different types of screening and cost analysis can occur during a technology's development. The first is decision analysis which is recommended for use in early stages of technology selection and analysis, and linear programming where the objective function is evaluated subject to various constraints. At later stages of technology development, the more rigorous cost-effectiveness analysis is undertaken. In general, it is best to compare a new technology with conventional or baseline technologies under various performance scenarios. From this can be projected the estimated cost savings or cost difference for a remediation task.
A life-cycle cost estimate study will be done by FEMP. At least one other study will probably be done by an independent firm selected by DOE. The estimates shall include all expenses for the entire life-cycle. Some, but not all, of the items to be included in the estimate are:

- RI/FS

- Development Studies

- Design

- Construction

- Waste Removal and Treatment

- Treated Waste Staging

- Treatment Operations

- Maintenance

- Treated Waste Transport

- at or near FEMP

- at a Western US disposal site

- Decontamination and Demolition

- Final Greenfielding

- Long-term Monitoring

\section{TECHNOLOGY NEEDS}

Life-cycle cost calculations on a total systems basis are necessary to validate the MAWS system as a cost-effective treatment option. The goal is a return on investment of 5 or greater, which is a tentative goal set for OTD projects. Primary savings are expected due to volume reduction, and further savings may be realized through delisting. Overall leveraging of the experience gained at the Fernald demonstration, when applied to other sites, will provide additional benefits. 


\section{ACCOMPLISHMENTS}

- Preliminary estimates for Fernald have shown that MAWS vitrification is more cost effective than cementation when processing and disposal costs based on volume are factored together.

- A minimum potential savings of $\$ 100 \mathrm{M}$ is projected in remediating the Fernald's Operable Unit 1.

- Additional unquantified cost savings may result over the longer term based on the demonstrated superior durability and leach resistance of glass compared to cement.

\section{COLLABORATION/TECHNOLOGY TRANSFER}

Contacts have been made with the Energy and Environmental Analysis Group at Los Alamos
National Laboratory to explore capabilities to perform life cycle cost analyses on the MAWS technology. It is anticipated that this activity will occur in FY94 after the completion of the demonstration at Fernald, and then again after selection and demonstration of a high temperature vitrification system.

For further information, please contact:

Mr. Rod Gimpel

Principal Investigator

FERMCO

(513) 648-6113 
4.0 MAWS APPLICATION AT FERNALD 
FEMP is a Federal facility that previously produced pure uranium for DOE. Production ended in 1989, and the site's mission has since been dedicated to environmental restoration. Process wastes containing low concentrations of uranium and thorium were stored in five onsite waste pits designated as Operable Unit 1 (OU-1); a significant portion of the FEMP wastes are listed as hazardous materials under the Resource Conservation and Recovery Act (RCRA) because they contain certain RCRA components. Studies have indicated that uranium contamination is present in the pit sludges and in the surrounding soils and groundwater.
The major factor affecting remediation cost at OU-1 is the large quantities of wastes needing remediation, i.e., approximately $360,000 \mathrm{~m}^{3}$ of pit wastes; up to $540,000 \mathrm{~m}^{3}$ of soil under the pits, in the caps, and in the berms; and about 2.3 million gallons of contaminated surface wastewater (See Figure 6). Because MAWS has been identified as a potentially costeffective treatment approach, the MAWS technology has been adopted as one of the treatment options for OU- 1 to be studied as input to the Record of Decision (ROD) scheduled for December 1994.

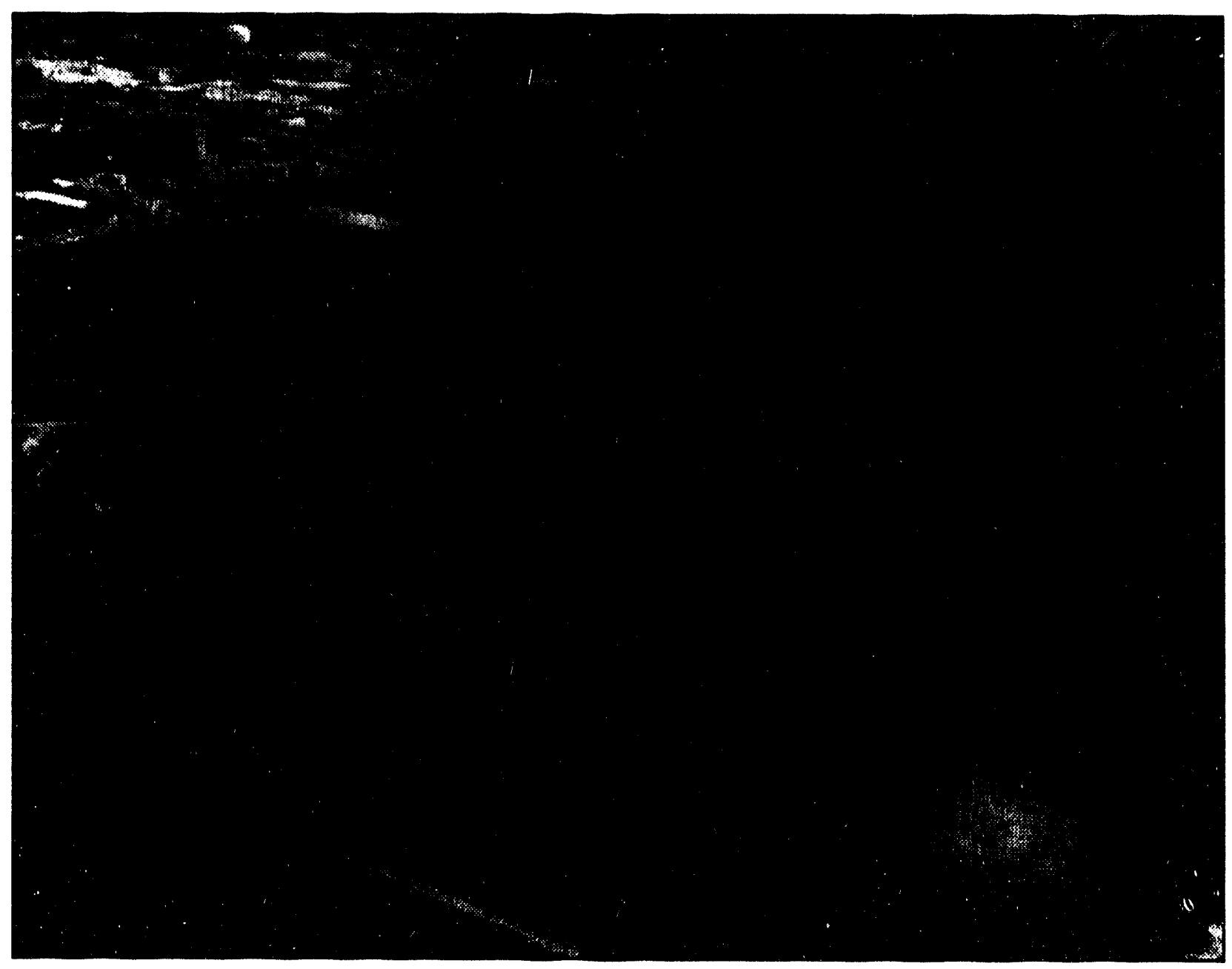

Figure 6. Large quantities of waste exist at Operable Unit 1 
Application of the MAWS concept may take many forms of integrated systems which will be dependent on the particular waste streams being combined. The particular integrated system chosen for Fernald consists of vitrification, soil washing, and ion exchange/water treatment (See Figure 7).

\subsubsection{Vitrification}

The Fernald variation of MAWS vitrification technology is directed at lower temperature processes in the range of 1100 to $1600^{\circ} \mathrm{C}$. At these elevated temperatures, glass becomes electrically conductive, and the current passing between the electrodes in a vitrifier causes the conductive glass to heat, thereby maintaining the glass in a molten state. This process is known as joule-heating. Most inorganics oxidize and dissolve in the molten glass because the great majority of oxides are soluble in silicate glasses; organics rapidly oxidize at the high temperatures and form simple gases (mostly carbon dioxide and water vapor) that are collected and treated in the offgas system.

Such a vitrification system (GTS Duratek Duramelter ${ }^{\mathrm{TM}}$ ) capable of producing at least $100 \mathrm{~kg} / \mathrm{d}$ of vitrified waste from radioactive feed materials is located at the Vitreous State Laboratory (VSL) of Catholic University of America. This system will provide critical large-scale process data necessary for the development of process controls and operating protocols for the $300-\mathrm{kg} / \mathrm{d}$ system installed at FEMP. Process data will include throughput rates, cold cap formation, and information on foaming events, as well as offgas system performance evaluation. Additionally, supporting data for scale-up to the larger pilot-scale and full-size units will continue to be collected from $10-\mathrm{kg} / \mathrm{d}$ and $100-\mathrm{kg} / \mathrm{d}$ units in conjunction with the $300-\mathrm{kg} / \mathrm{d}$ system to be used for the demonstration.

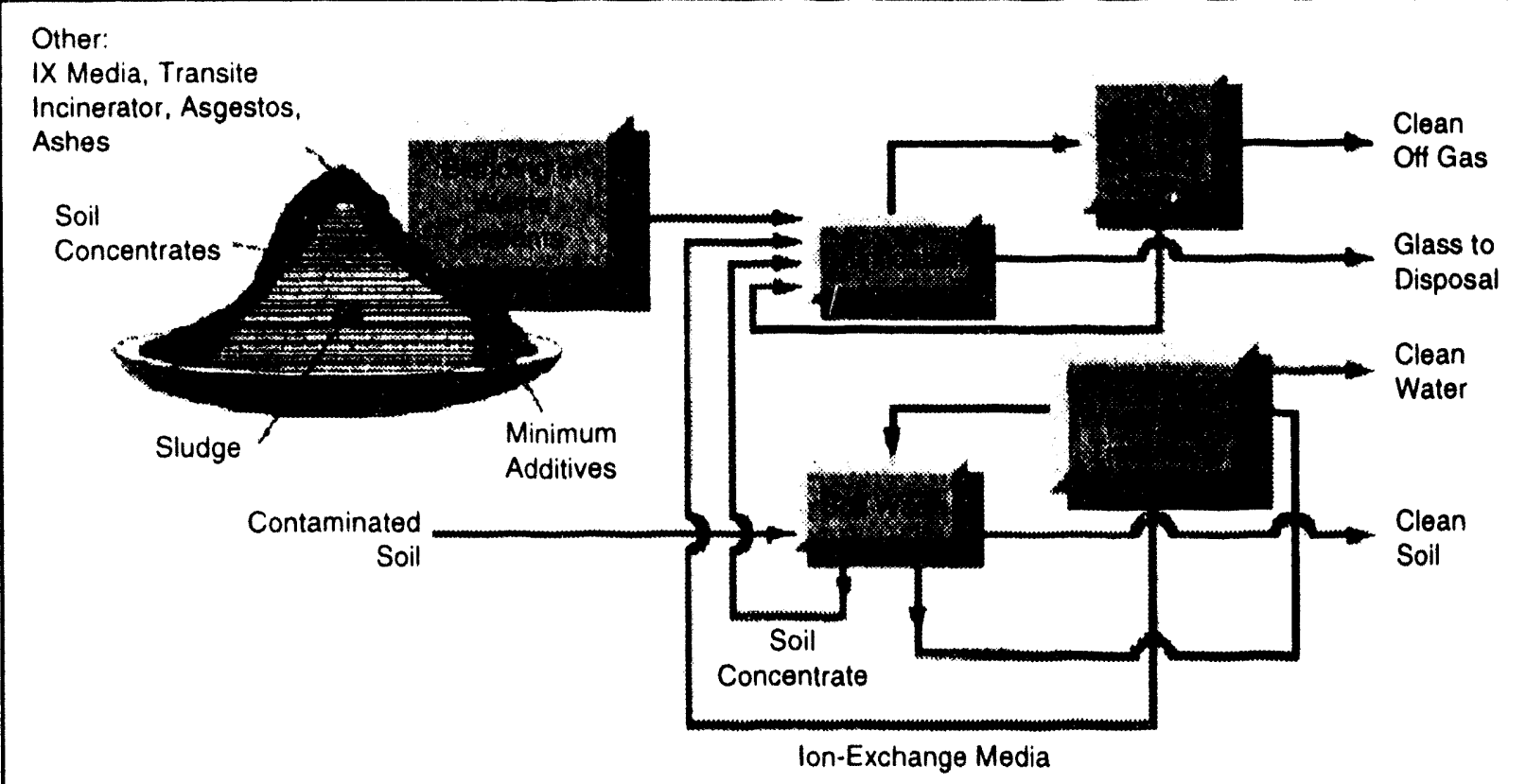

Figure 7. The MAWS Technology System. 


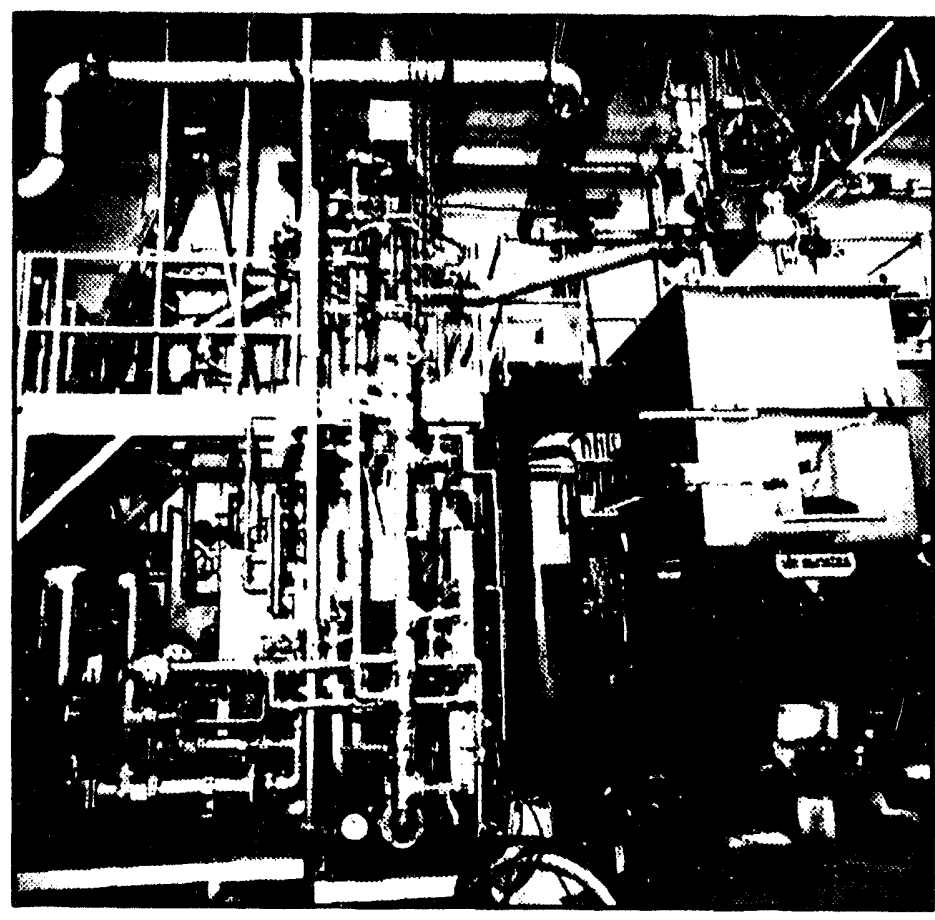

Figure 8. The FEMP Vitrification and Off-gas System.

The vitrification system to be demonstrated at FEMP will produce $300 \mathrm{~kg} / \mathrm{d}$ of glass from radioactive waste. An extensive on-site testing program will be conducted to provide the essential system performance and operating data necessary for treatment technology selection at FEMP. These data will also provide the basis for scale-up to larger pilot-scale and fullscale treatment systems. The FEMP vitrification system has been designed to handle a blend of pit sludges, spent resins, and soil concentrates (See Figure 8). This MAWS system will be capable of dispensing the vitrified product into drums in the form of glass gems. The gems will be of various sizes to facilitate packing and enhance volume reduction while maintaining easy handling of the vitrified product.

The off-gas system will have an advanced two-stage caustic scrubbing system designed to produce no secondary waste streams. The off-gases will then be treated by high-efficiency particulate air (HEPA) filtration to meet regulatory requirements for release. Produced sludges will be recycled to the melter. Monitoring equipment will also be provided.

\subsubsection{Soil Washing}

Soils, primarily contaminated with radioactive constituents, will be washed with the TRUclean ${ }^{\mathrm{T} M}$ process to separate them into clean soils and soil concentrates. This will be accomplished by passing a slurry of the contaminated soils through a series of scrubbers, gravimetric separators, and hydrocyclone separators. Laboratory studies of FEMP soils have been performed to specify the demonstration unit, and a carbonate leach step has been added to achieve the target uranium cleanup level. The demonstration unit at FEMP is able to process $0.25 \mathrm{yd}^{3} / \mathrm{h}$ of soil (see Figure 9). The soil concentrates will be used as feed for the vitrification system. All input and output streams will be analyzed for contaminants to deterinine

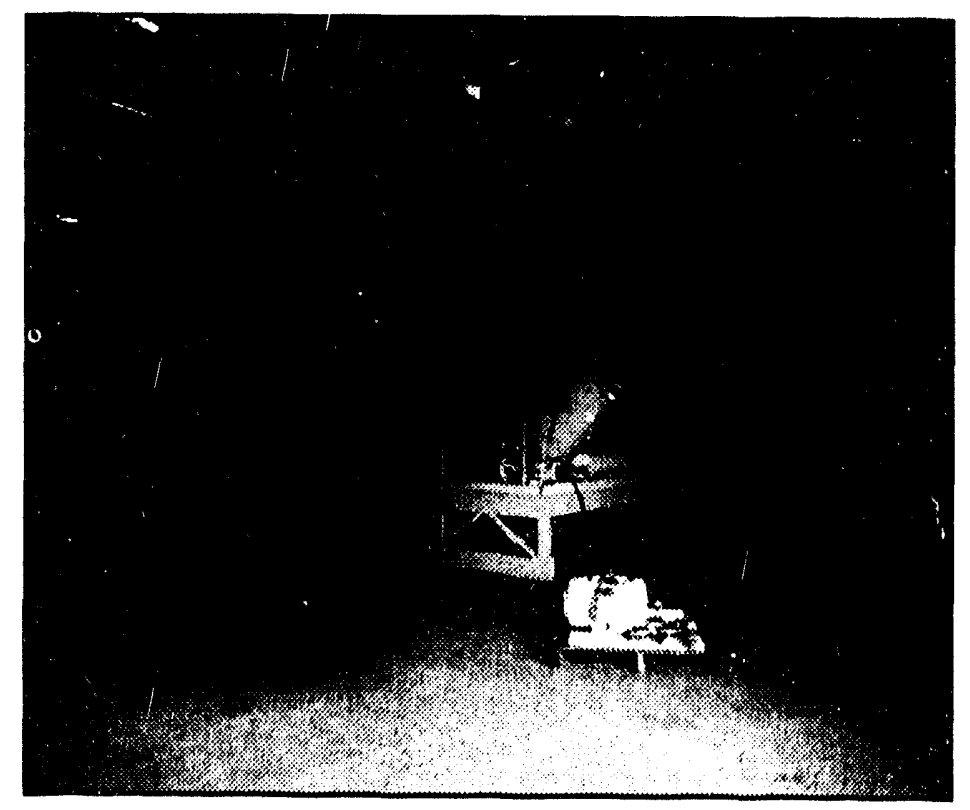

Figure 9. The FEMP Soll Washing System. 
the success of the soil washing for radionuclide removal and other RCRA contaminants, if appropriate. Mass balance calculations will verify final disposition of the contaminants. These studies are being conducted in close collaboration with the laboratory water treatment studies to ensure that the effluent from the process can be treated in the ion-exchange system and then recycled to the melter for ultimate stabilization of the contaminants in the vitrified glass product.

\subsubsection{Ion Exchange Water Treatment}

The water treatment system will treat contaminated wastewater from the soil washing systems. Uranium and thorium contaminants will be stripped of by a traditional organic ion-exchange resin and redeposited onto a glass resin that can be fed to the vitrifier, allowing for conventional disposal of the spent organic resin. The success and economics of this process will be evaluated and documented at the end of the FEMP demonstration. If necessary, the process can be modified to remove hazardous constituents, such as toxic metals, to ensure that all water quality standards are met for water discharged from the system. An acid-stripping process will be developed for regenerating the Dowex $21 \mathrm{~K}$ organic ion-exchange resin used in the water treatment system. The stripped uranium will then be collected and used as feed for the melter.

A 10-gpm to 100-gpm water treatment system, capable of removing uranium from the influent to levels below $20 \mathrm{ppb}$, is installed at FEMP. Operating parameters for the system will be optimized by performing laboratory studies using soil wash waters as the influent. 
In July 1992, a joint venture was established between the DOE Office of Technology Development and the Office of Environmental Restoration within the Office of Environmental Restoration and Waste Management to demonstrate the MAWS process at the Fernald OU-1 site. The contractors participating in this demonstration include GTS Duratek Corporation (vitrification testing and wastewater treatment), Catholic University of America (vitrification testing), and Lockheed Environmental Services Corporation (soil washing). On-site support is being provided by FEMP management and their subcontractors. Contract management and glass durability testing is being provided by Argonne National Laboratory.

In preparation for the commercial demonstration of the MAWS technology at Fernald, the scale-up was divided into two phases. The first phase involved the laboratory development of the specific compositional envelope for OU-1, pit 5 wastes which include both batch crucible studies and continuous bench scale demonstrations at the $10-\mathrm{kg} /$ day and $100-\mathrm{kg} /$ day scale. This phase of the work was supported by the Office of Technology Development EM-50. The second phase of work to begin in October 1993 will demonstrate the full system involving a $300-\mathrm{kg} /$ day continuous melter along with the soil washing and water treatment processes onsite at Fernald. Support for this phase will come primarily from the Office of Environmental Restoration EM-40.

\subsubsection{Phase I- Lab Development}

The MAWS technology was adopted by FEMP for demonstration because the site wastes (contaminated soils and sludges) contain both the glass former and the flux resources necessary for glass making. Waste characterization studies have been conducted to identify these glass-forming components. A crucible melt study (see Figure 10) has been designed which varies compositional combinations of soil-wash concentrates, OU-1 sludges, flyash, spent ion-exchange media, and other identified wastes - with and without

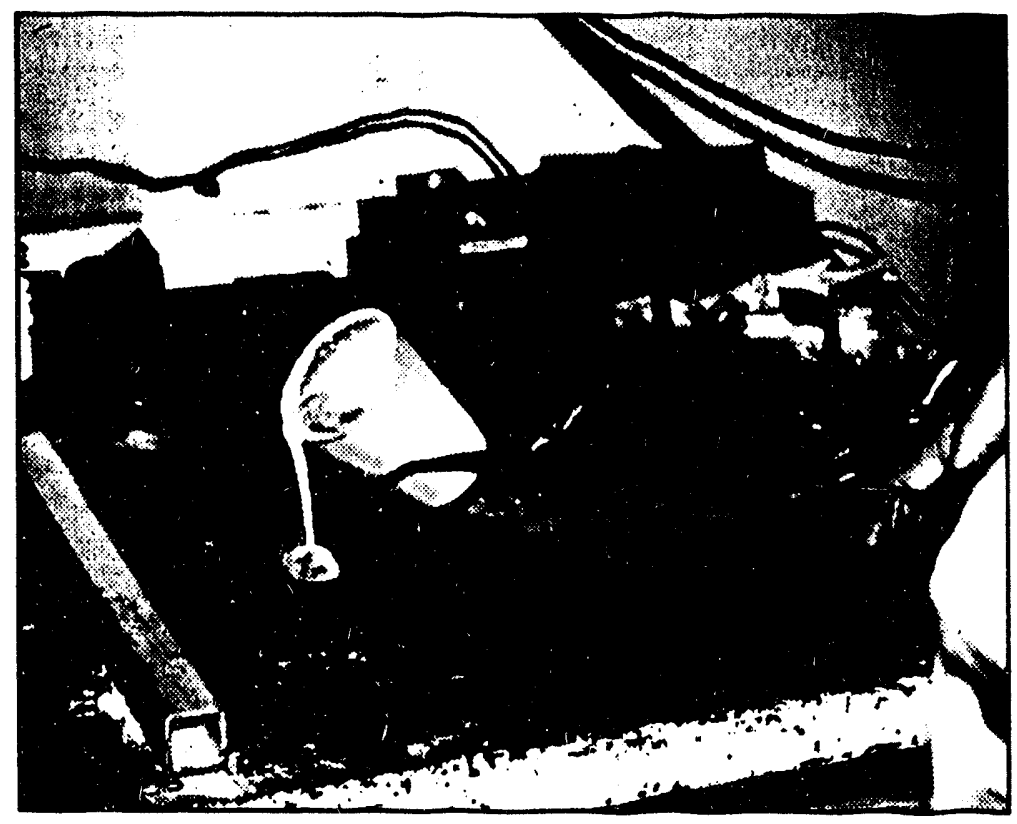

Figure 10. Crucible Melt Studies.

the addition of chemical additives. Through use of glass property characterization and modeling the optimal blend of wastes that will satisfy processing parameter constraints (mainly melt viscosity, electrical conductivity, and liquidus temperature) and at the same time produce a leach-resistant, durable glass waste form with high waste loading has been 
determined. Characterization and laboratory development has provided information about any components in the waste that may hinder the vitrification process and, thus, will inaicate when pretreatment of the waste may be necessary. Small-scale testing $(10 \mathrm{~kg} / \mathrm{d}$ glass output) in a continuous joule-heated melter has been conducted to obtain processing and off-gas performance data.

\section{ACCOMPLISHMENTS}

Key accomplishments from this phase of the study have been:

Testing of the radioactive glass produced in the $10-\mathrm{kg} / \mathrm{d}$ melter has been conducted. The final glasses passed the TCLP test and compared favorably with the high-level waste glass in the initial glass characterization. Long-term durability testing of the radioactive glass product has been initiated and appear favorable.

- Tests with radioactive wastes have been completed in the $10-\mathrm{kg} / \mathrm{d}$ melter. High levels of hydrogen fluoride in the off-gas have been effectively treated, with up to a fivefold volume reduction, which has provided crucial data for the specification and subsequent testing of both the $100-\mathrm{kg} / \mathrm{d}$ and $300-\mathrm{kg} / \mathrm{d}$ melters.

- The $100-\mathrm{kg} / \mathrm{d}$ melter and off-gas system has been constructed and operated with both simulated and radioactive wastes.

- A laboratory-scale water treatment system has been installed and successfully operated for laboratc y soil washing tests.

- Results from laboratory-scale soil washing tests have achieved a reduction in uranium concentration to less than 35
$\mathrm{pCi} / \mathrm{g}$ and a volume reduction of greater than $80 \%$. These tests produced radioactive soil concentrates for vitrification. Specification of the soil washing demonstration unit has been completed.

- The on-site MAWS 300-kg/day demonstration system is under fabrication/ delivery and is scheduled for start-up at FEMP in October 1993.

For further information regarding the Fernald application, please contact:

\section{Ms. Grace Ordaz}

Program Manager

Department of Energy

(301) 903-7440

Ms. Denise Freeman

Program Manager

Department of Energy

(301) 903-7633

Ms. Sharon Fauver

Program Manager

Department of Energy

(301) 903-7667

Mr. Rod Warner

Principal Investigator

DOE-Fernald

(513) 648-3156

Dr. Ian Pegg

Principal Investigator

Catholic University, VSL

(201) 319-6700

Mr Carlos Tellez

Principal Investigator

Lockheed Env. Serv.

(702) 361-0740 


\subsubsection{Phase II- Site Demonstration}

Phase II comprises the "hot" start-up, operation, and demonstration of the MAWS $300-\mathrm{kg} /$ day system at FEMP. Limited continued operation of the MAWS $100-\mathrm{kg} /$ day facility at Catholic University VSL will also support Phase II. Within this site demonstration there are a number of specific tasks:

- Prove the MAWS Concept - Employ the most successful formula developed from the $100-\mathrm{kg} /$ day melter studies at VSL while trying to achieve high waste loading, low use of additives, and ease of processing. A continuous campaign should achieve steady state operation with routine sampling practices and statistically consistent quality glass.

- Develop Process Control - Process control strategies will be developed that can detect, measure, and record process parameter changes in order to make appropriate adjustments to insure continual process production and safety, glass quality, and equipment integrity. In depth training will be an integral part of the overall control strategy.

- Develop Operational and Compositional Envelope - The operational envelope shall include all the process parameters affecting the final product characteristics and safe process control. The compositional envelope shall include studies to define flexibility in handling variable feed streams from a single source as to content of glass forming agents and fluxing agents, and from other sources at the site such as asbestos or silo wastes. Also, this may extend to waste streams at other DOE sites to leverage the existing work.
- Equipment Erosion Inspection - Upon completion of the campaign the equipment shall be inspected for erosion/corrosion to determine the expected life of the various components in the system.

- Waste Form Performance Evaluation and Test Development - Long term waste durability studies will be performed to assess the quality and stability of the glasses produced for meeting the various standards.

- Waste Vitrification Run With Pure Sand - A baseline/benchmark test will be conducted using pure sand to replace the FEMP soil components at the highest practical waste loading. This will be tested at the bench-scale and in the $300-\mathrm{kg} /$ day melter.

- Soil Washing and Soil Variability - The soil wash system shall feed the melter on an as-needed basis and provide capability for washing 0.25 cubic yards per hour or greater. Soils for the process may come from various FEMP locations.

- Water Treatment - Treatment of water from the soil washing operations shall be demonstrated with recycle of all contaminants back to the melter.

- Delisting - Testing will be carried out to provide the required data for a decision on whether the final vitrified waste form can be delisted thereby providing greater flexibility in the options for final disposal.

- Remaining FEMP Waste Pit Development - Evaluations of FEMP waste pits $1,2,3,4,6$, Clearwell, and 
Burnpit will be done as funding permits to determine if they fall within the established compositional envelope or require further evaluation on the $100-\mathrm{kg} / \mathrm{d}$ or $300-\mathrm{kg} / \mathrm{d}$ melters.

The status of Phase II work is that the $300-\mathrm{kg} /$ day melter along with the soil wash and ion exchange systems are on-site at FEMP and scheduled for start-up in October 1993. 
The MAWS concept integrates vitrification with soil washing and ion-exchange wastewater

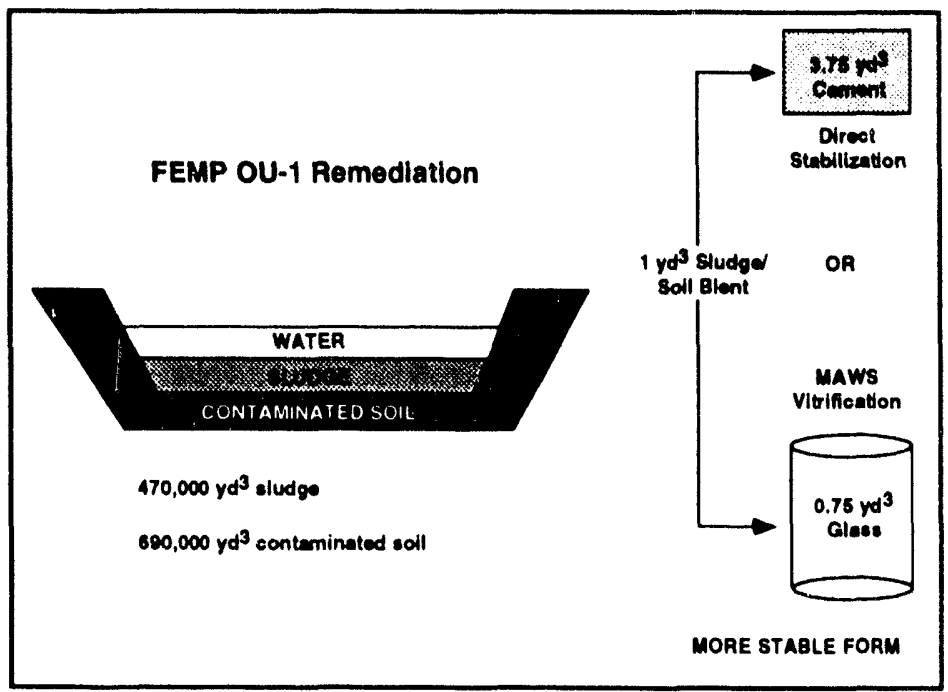

Figure 11. Enhanced Volume Reduction.

treatment, and uses various wastes for resources as vitrification additives, thereby minimizing the use of purchased additives. As a result, waste loading is increased, and the final waste volume, as well as the disposal cost, can be significantly reduced (see Figure 11 ). In addition, the long-term stability/durability of a vitrified waste is many times greater than an alternate cement form.

The soil washing and wastewater treatment remediates contaminated soil and groundwater whereas the vitrification system incorporates the pit sludge and resulting secondary waste streams (contaminated soil concentrates and spent ion-exchange resins) into a final, stabilized glass waste form. This systematic approach further maximizes waste loading while eliminating secondary waste streams. Use of the MAWS system at Fernald is expected to save up to $55 \%$ of the cost compared with the conventional cementation treatment method (see Figure 12 ) or roughly $\$ 720 \mathrm{M}$ in remediation costs for OU-1 alone. Comparing worst case engineering estimates for vitrification versus best case estimates for cementation, a minimum of $\$ 100 \mathrm{M}$ savings is projected. For a more detailed breakdown of these cost estimates, refer to Appendix A. When these projections are carried out for additional OU's at Fernald or other DOE sites, the cost savings are enormous.
This vitrification system demonstration will potentially provide a basis for the adoption of in-furnace vitrification as the EPA best demonstrated available technology for selected multiple waste streams, such as raffinate

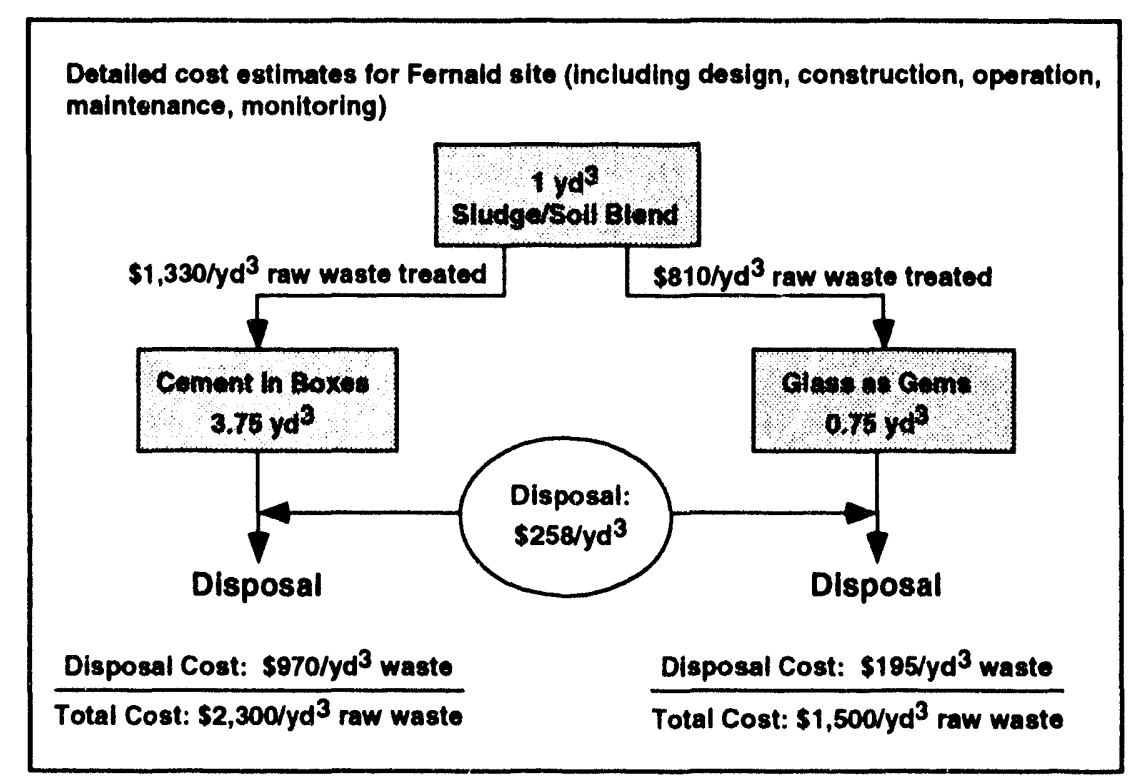

Figure 12. Benefits of Volume Reduction at Fernald. 
sludges and soils (similar to adoption of vitrification for high-level wastes). Such a change would greatly expedite remediation programs at many DOE sites that may otherwise be forced to comply with leachresistance requirements for mixed waste forms (beyond passing the TCLP test). This is an area in which appropriate regulations, and even consensus test methods, are stili being developed.

The potential exists that the final waste glass form might qualify for delisting, in which case the final disposal costs could be even less since fewer barriers need to be constructed to contain the material. This is due to the generally superior leach characteristics of glass compared to cement or grouts. Through good engineering of the glass compositional envelope, this option will be pursued as more test data from the demonstration become available. 


\section{WORKING WITH THE DOE OFFICE OF ENVIRONMENTAL RESTORATION AND WASTE MANAGEMENT}

The Department of Energy (DOE) provides a range of programs and services to assist universities, industry, and other private-sector organizations and individuals interested in developing or applying environmental technologies. Working with DOEOperations Offices and management and operating (M\&O) contractors, EM uses conventional and innovative mechanisms to identify, integrate, develop, and adapt promising emerging technologies. These mechanisms include contracting and collaborative arrangements, procurement provisions, licensing of technology, consulting arrangements, reimbursable work for industry, and special consideration for small business.

\section{Cooperative Research and Collaborative Arrangements}

EM will facilitate the development of subcontracts, R\&D contracts, and cooperative agreements to work collaboratively with the private sector.

EM uses Cooperative Research and Development Agreements (CRADAs) as an incentive for collaborative R\&D. CRADAs are agreements between a DOE R\&D laboratory and any non-Federal source to conduct cooperative R\&D that is consistent with the laboratory's mission. The partner may provide funds, facilities, people, or other resources. DOE provides the CRADA partner access to facilities and expertise; however, no Federal funds are provided to external participants. Rights to inventions and other intellectual property are negotiated between the laboratory and participant, and certain data that are generated may be protected for up to 5 years.

Consortia will also be considered for situations where several companies will be combining their resources to address a common technical problem. Leveraging of funds to implement a consortium can offer a synergism to overall program effectiveness.

\section{Procurement Mechanisms}

DOE EM has developed an environmental management technology development acquisition policy and strategy that uses phased procurements to span the RDDT\&E continuum from applied R\&D concept feasibility through full-scale remediation. DOE EM phased procurements make provisions for unsolicited proposals but formal solicitations are the preferred responses. The principle contractual mechanisms used by EM for industrial and academic response include Research Opportunity Announcements (ROAs) and Program R\&D Announcements (PRDAs). In general, EM Technology Development uses ROAs to solicit proposals for R 2 D projects and PRDAs for proposals for its DT\&E projects. 
EM uses the ROA to solicit advanced research and technologies for a broad range of cleanup needs. The ROA supports applied research ranging from concept feasibility through full-scale demonstration. In addition, the ROA is open continuously for a full year following the date of issue and includes a partial set-aside for small businesses. Typically, ROAs are published annually in the Federal Register and the Commerce Business Daily, and multiple awards are made.

PRDAs are program announcements used to solicit a broad mix of R\&D and DT\&E proposals. Typically, a PRDA is used to solicit proposals for a wide-range of technical solutions to specific EM problem areas. PRDAs may be used to solicit proposals for contracts, grants, or cooperative agreements. Multiple awards, which may have dissimilar approaches or concepts, are generally made. Numerous PRDAs may be issued each year.

In addition to PRDAs and ROAs, EM uses financial assistance awards when the technology is developed for public purpose. Financial assistance awards are solicited through publication in the Federal Register. These announcements are called Program Rules. A Program Rule can either be a one-time solicitation or an open-ended, general solicitation with annual or more frequent announcements concerning specific funding availability and desired R\&D agreements. The Program Rule also can be used to award both grants and cooperative agreements.

EM awards grants and cooperative agreements if 51 percent or more of the overall value of the effort is related to a public interest goal. Such goals include possible non-DOE or other Federal agency participation and use, advancement of present and future U.S. capabilities in domestic and international environmental cleanup markets, technology transfer, advancement of scientific knowledge, and education and training of individuals and business entities to advance U.S. remediation capabilities.

\section{Licensing of Technology}

DOE contractor-operated laboratories can license DOE/EM-developed technology and software to which they elect to take title. In other situations where DOE owns title to the resultant inventions, DOE's Office of General Counsel will do the licensing. Licensing activities are done within existing DOE intellectual property provisions.

\section{Technical Personnel Exchange Assignments}

Personnel exchanges provide opportunities for industrial and laboratory scientists to work together at various sites on environmental restoration and waste management technical problems of mutual interest. Industry is expected to contribute substantial cost-sharing for these personnel exchanges. To encourage such collaboration, the rights to any resulting patents go to the private sector company. These exchanges, which can last from 3 to 6 months, are opportunities for the laboratories and industry to understand better the differing operating cultures, and are an ideal mechanism for transferring technical skills and knowledge. 


\title{
Consulting Arrangements
}

Laboratory scientists and engineers are available to consult in their areas of technical expertise. Most contractors operating laboratories have consulting provisions. Laboratory employees who wish to consult can sign non-disclosure agreements, and are encouraged to do so.

\section{Reimbursable Work for Industry}

DOE laboratories are available to perform work for industry, or other Federal agencies, as long as the work pertains to the mission of a respective laboratory and does not compete with the private sector.

The special technical capabilities and unique facilities at DOE laboratories are an incentive for the private sector to use DOE's facilities and contractors expertise in this reimbursable work for industry mode. An advanced class patent waiver gives ownership of any inventions resulting from the research to the participating private sector company.

\section{EM Small Business Technology Integration Program}

The EM Small Business Technology Integration Program seeks the participation of small businesses in the EM Research, Development, Demonstration, Testing and Evaluation (RDDT\&E) programs. Through workshops and frequent communication, the EM SB-TIP provides information on opportunities for funding and collaborative efforts relative to advancing technologies for DOE environmental restoration and waste management applications.

EM SB-TIP has established a special EM procurement set-aside for small firms (500 employees or less) to be used for applied research projects, through its ROA. The program also serves as the EM liaison to the DOE Small Business Innovation Research (SBIR) Program Office, and interfaces with other DOE small business offices, as well.

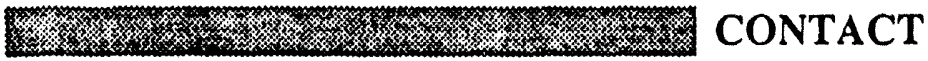

\author{
David W. Geiser, Acting Director \\ International Technology Exchange Division \\ EM-523 \\ Environmental Restoration and Waste Management \\ Technológy Development \\ U.S. Department of Energy \\ Washington, D.C. 20585 \\ (301) $903-7640$
}

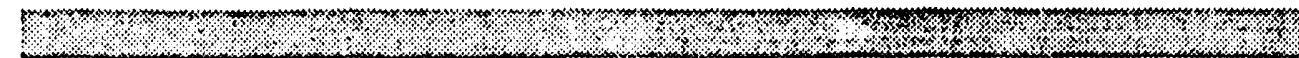




\section{EM Central Point of Contact}

The EM Central Point of Contact is designed to provide ready access to prospective research and business opportunities in waste management, environmental restoration, and decontamination and decommissioning activities, as well as information on EM-5() IPs and IDs. The EM Central Point of Contact can identify links between industry technologies and program needs, and provides potential partners with a connection to an extensive complex-wide network of Headquarters and field program contacts.

The EM Central Point of Contact is the best single source of information for private-sector technology developers looking to collaborate with EM scientists and engineers. It provides a realtime information referral service to expedite and monitor private-sector interaction with EM.

To reach the EM Central Point of Contact, call 1-800-845-2096 during normal business hours (Eastern time).

\section{Office of Research and Technology Applications (ORTAs)}

ORTAs serve as technology transfer agents at the Federal Laboratories, and provide an internal coordination in the laboratory for technology transfer and an external point of contact for industry and universities. To fulfill this dual purpose, ORTAs license patents and coordinate technology transfer activities for the laboratory's scientific departments. They also facilitate one-on-one interactions between the laboratory's scientific personnel and technology recipients, and provide information on laboratory technologies with potential applications in private industry for state and local governments.

\section{For More Information}

For more information about these programs and services, please contact:

Claire Sink, Director

Technology Integration Division

EM-521

Environmental Restoration and Waste Management Technology Development

U.S. Department of Energy

Washington, D.C. 20585

(301) 903-7928 
ANL - Argonne National Laboratory

CERCLA - Comprehensive Environmental Response, Compensation, and Liability Act

CFR - Code of Federal Regulations

CRADA - Cooperative Research and Development Agreement

CUA - Catholic University of America

DOE - Department of Energy

DT\&E - Demonstration, Testing and Evaluation

EM - Environmental Restoration and Waste Management

ERMC - Environmental Restoration Management Contractor

FEMP - Fernald Environmental Management Project

FRESH - Fernald Residents for Environmental Safety and Health

FY - Fiscal Year

HEPA - High Efficiency Farticulate Air filtration

ID - Integrated Demonstration

IP - Integrated Program

MAWS - Minimum Additive Waste Stabilization

M\&O - Management and Operating

NPR - National Priorities List

ORTA - Office of Research and Technology Applications

OTD - Office of Technology Development

OU - Operable Unit

PCB - Poly-Chlorinated Biphenyl

PCF - Plasma Centrifugal Furnace

PCT - Product Consistency Test

PETC - Pittsburgh Energy Technology Center

PRDA - Program Research and Development Announcement

RCRA - Resource Conservation and Recovery Act

RDDT\&E - Research, Development, Demonstration, Testing and Evaluation

RI/FS - Remedial Investigation/Feasibility Study

ROA - Research Opportunity Announcement

ROD - Record of Decision 
SB-TIP - Small Business Technology Integration Program

SITE - Superfund Innovative Technology Evaluation

TCLP - Toxicity Characteristic Leach Procedure

TSCA - Toxic Substances Control Act

TTP - Technical Task Plan

VSL - Vitreous State Laboratory

WEMCO - Westinghouse Environmental Management Company of Ohio 
ceramic. Materials made from nun-metallic minerals such as clays at high temperatures through firing which fuses grain boundaries.

cold cap. The practice of piling the relatively cool glass/waste feed on the surface of the melt to act as an insulation blanket and to reduce volatilization from the melt.

crystal. A homogeneous matter possessing a triperiodic structure on the atomic scale.

disposal. Waste emplacement designed to ensure isolation of waste from the biosphere, with no intention of retrieval for the foreseeable future, and requiring deliberate action to regain access to the waste.

environmental restoration. Cleanup and restoration of sites contaminated with hazardous substances during past production or disposal activities.

glass. A homogeneous or heterogeneous amorphous solid, without periodic structure.

glass additives. Components comprising the glass made up of network formers, fluxes, and intermediates. Examples are sand, soda ash, borax, lime.

glass fluxing agent. In a glass these are the network breakers such as soda and calcia which terminate the three dimensional inorganic polymer structure.

glass intermediate. In a glass these are components which act like both fluxes and structure makers but usually only in two as opposed to three dimensions. Usually oxidized metals that may tend to promote crystallization as temperature drops.

glass structure/network formers. In a glass these are components such as silica and alumina which compose the three dimensional inorganic polymer network.

hazardous waste. As defined in RCRA, a solid waste or combination of solid wastes that, because of its quantity, concentration, or physical, chemical, or infectious characteristics, may cause or significantly contribute to an increase in mortality or an increase in serious, irreversible, or incapacitating reversible illness or pose a substantial present or potential hazard to human health or the environment when improperly treated, stored, transported, disposed of, or otherwise managed.

high-level waste. The highly radioactive waste material that results from the reprocessing of spent nuclear fuel, including liquid waste produced directly in reprocessing and any solid waste derived from the liquid, that contains a combination of transuranic waste and fission products in concentrations requiring permanent isolation. 
incineration. A treatment technology using combustion to destroy organic constituents and reduce the volume of wastes.

joule heated melter. A thermal treatment technology in which electrodes are placed in the glass melt and an electric current provides the source of heat due to the resistance of the melt.

leach resistance. The ability of a solid to resist becoming soluble in an aqueous media.

low-level waste. Radioactive waste not classified as high-level waste, transuranic waste, spent nuclear fuel, or by-product material.

metal. An opaque, fusible, ductile, and typically lustrous substance that is a good conductor of electricity and heat, and that forms cations by loss of electrons, and yields basic oxides and hydroxides. Metals are generally formed in a reducing atmosphere.

mixed waste. Waste containing both radioactive and hazardous components, as defined by the Atomic Energy Act and RCRA.

off-gas. Gases evolved or generated during a thermal treatment process such as incineration or vitrification.

operable unit. The cleanup of a site can be divided into a number of operable units, depending on the complexity of the problems associated with the site. Operable units may address geographical portions of a site, specific site problems, or initial phases of an action or may consist of any set of actions performed over time or any actions that are concurrent but located in different parts of a site.

plasma. A hot ionized gas composed of nearly equal numbers of electrons and positive ions: it can be confined and compressed by a magnetic field. It can be used to thermally destroy organics/ combustibles and vitrify remaining solids.

radioactive waste. A solid, liquid, or gaseous material of negligible economic value that contains radionuclides in excess of threshold quantities; does not include material contaminated by radionuclides from nuclear weapons testing.

record of decision. The CERCLA document used to select the method of remedial action to be implemented at a site after the feasibility study/proposed plan process has been completed.

sanitary waste. Wastes, such as garbage, that are generated by normal housekeeping activities and that are not hazardous or radioactive. 
slag. In metal refining - a scum or impurity that forms on the surface of a metal during thermal processing. Usually slag consists of various inorganic materials that may take either glasseous, crystalline, metallic, or mixed forms.

spent nuclear fuel. Irradiated nuclear reactor fuel before reprocessing; contains uranium, fission products, and transuranic elements.

stabilization. The act of rendering a waste immobile or safe for handling and disposal.

transuranic waste. Waste that is contaminated with alpha-emitting radionuclides with an atomic number greater than 92 (heavier than uranium), half-lives greater than 30 years, and concentrations greater than 100 nanocuries per gram of waste.

treatment. Any activity that alters the chemical or physical nature of a hazardous waste to reduce its toxicity, volume, mobility, or render it amenable for transport, storage, or disposal.

vitrification. A high temperature process of immobilizing waste that produces a glass-like solid that permanently captures the radioactive waste.

waste stream. Terminology used to refer to waste leaving a facility or operation. 


\section{APPENDIX A}

\section{LETTER REPORT}

\section{MINIMUM ADDITIVE WASTE STABILIZATION (MAWS) TECHNOLOGY - SCOPING COST SAVINGS ANALYSIS}

December 10, 1993

MAWS Program Manager

Grace Ordaz 


\section{MINIMUM ADDITIVE WASTE STABILIZATION (MAWS) TECHNOLOGY - SCOPING COST SAVINGS ANALYSIS}

This analysis was prepared internally by OTD with inputs from the field as an initial scoping estimate for the remediation of Fernald OU-1. The results shown reflect the engineering confidence in these analyses which is $+30 /-50$ percent, and only hold for the assumptions and scenarios outlined herein, which are believed to be realistic based on current knowledge.

\section{CONCLUSIONS}

- Total projected vitrification (MAWS) treatment and disposal life cycle costs are from $\$ 700$ to $\$ 1300$ per cubic yard of waste.

- Total projected cementation (possible baseline approach) treatment and disposal life cycle costs are from $\$ 1500$ to $\$ 3000$ per cubic yard of waste.

- The potential cost savings projected for Fernald OU-1 alone is a minimum of $\$ 100$ million.

- The primary cost differences are driven by the disposal volume and required containerization assumed in the cementation scenario.

- The potential Return on Investment for Fernald OU-1 alone is a minimum of 6:1, and may potentially be much larger when applied across the DOE complex.

- Several other DOE sites including Hanford, Oak Ridge, and Savannah River are considering a MAWS approach to some of their waste problems.

\section{BACKGROUND}

The Fernald Environmental Management Project (FEMP) in Fernald, Ohio is a Federal facility that previously produced high-purity uranium metal which was fabricated into fuel cores and target elements for use in nuclear reactors at other DOE sites. Production ended in 1989, and the sites's mission has since been dedicated to environmental restoration. Process wastes containing low concentrations of uranium and thorium were stored in eight on-site waste pits designated as Operable Unit 1 (OU-1); a significant portion of the FEMP wastes are listed as hazardous under the RCRA, because they contain certain RCRA components (heavy metals and organics). Studies have indicated that uranium contamination is present in the pit sludges, surrounding soils, and groundwater.

The volume of waste estimated to exist in the eight OU-1 pits is roughly 467,000 cubic yards of sludges. The surrounding contaminated soils are estimated to comprise another 720,000 cubic yards. Soil washing is to be applied to reduce the soil volume to roughly 90,000 cubic yards so that the total volume of waste to be treated and disposed of is 557,000 cubic yards. These are 
low-level mixed wastes, and as such, regulations do not require vitrification as the treatment option, however this scoping analysis shows that it is a cost-effective as well as an environmentally advantageous approach to this problem.

Westinghouse was the early management contractor at Fernald and had engaged Parsons, an engineering firm, to do an initial scoping cost analysis in early 1993. The two treatment scenarios under consideration at that time were either cementation or vitrification using the MAWS approach. Disposal options considered were for either near-site disposal as a tumulus or to a far-site disposal facility in Utah (if permitting could not be obtained for the former option). More recently Fluor Daniel has become the management contractor, and a third option of drying the waste with shipment to Envirocare in Utah is being considered. The full analyses of these treatment and disposal costs have not yet been evaluated, nor have the environmental concerns been fully addressed. Therefore, this option is not considered further in this scoping analysis.

\section{ASSUMPTIONS}

\section{General}

- Although the contents of the eight pits vary in composition, all will be treated in the same manner with the selected treatment scenario.

- The volume of soil to be disposed of can be reduced significantly by soil washing, which should result in only 90,000 cuyd for disposal. Tinis is a cost-effective approach for all scenarios. Soil washing results in a more siliceous fraction for treatment.

- Near site disposal costs are estimated to be $\$ 258 /$ cuyd of final waste form. This would be multiplied by the volume factor increase/decrease for each treatment scenario.

\section{Cementation Scenario}

- The cementation volume factor increase is roughly 3.75 . This is due to the difficulty of immobilizing technetium ( $\mathrm{Tc}$ 99) which is present in the waste, and to achieve a $500 \mathrm{psi}$ grout waste form. Fly ash is used as an additive.

- Cementation will require placement in $4 \times 4 \times 8$ foot steel B25 containers to serve both as a mold and for ease of handling the finished blocks.

- The cementation option is for a single, large plant including slurry/retrieval, dewatering, batch mixing, pouring/setting, and $7-21$ day staging/QA operations. This is more labor intensive. A finite reject rate must be considered. Online operation factor is $250 \mathrm{day} / \mathrm{yr}$.

\section{Vitrification (MAWS) Scenario}

- The glass volume factor decrease is roughly 0.75 . This is a conservative estimate based on moisture of sludge, organics in soil, and waste loading percentage. The actual volume decrease could be closer to 0.50 . 
- The vitrification option is for 4 equally sized melter systems, each at about 80 tons/day capacity and projected to complete operations in 10 years. The online operational rate is projected to be $75 \%$, or normally three operational and one system down for maintenance. Operations include slurry/retrieval, mixing, melting, handling of glass gems, and waste water treatment.

- Glass (as gems) does not require placement into a container as it will pass leach test requirements in that waste form.

\section{SCENARIO ANALYSES}

The attached table was derived from the Parsons' estimates [WEMCO working level notes] and from adjustments based on field refinements to these scenarios using more current data on vitrification and cementation operational requirements. The Parsons' estimates carry an engineering confidence factor of $+30 /-50$ percent. The adjustments were made with the consensus of several field process engineers familiar with the project.

Columns A and B show the total life cycle cost estimates for vitrification. The vitrification option includes soil washing and waste water treatment processes such that no secondary wastes are generated.

Column A is the estimate from Parsons. This initial estimate assumed that 180,000 cuyd of soil and sand would need to be added to the sludge to make an acceptable glass, and the final form would be a glass frit with a void fraction of about $50 \%$. Also, it was assumed that the glass frit would be placed into containers (probably due to dust and small particle size fractions that would lead to higher leachability). This greatly increased the final cost of the treated waste, since a larger facility, expanded operations, and subsequent larger disposal volume are required. Treatment costs averaged over the total volume of sludge plus soil and sand additive is $\$ 1200$ per cuyd, which includes the cost of containers. Average disposal costs are $\$ 400$ for a total estimated cost of $\$ 1600$ per cuyd.

Column B reflects the adjusted vitrification scenario where the final form is glass gems. These have an estimated void packing volume of only $25 \%$, and do not require containerization before placing into lined pits. In addition, it was found that the soil washing increases the siliceous fraction of the soil such that the 90,000 cuyd of sand additive can be eliminated. These combined adjustments translate into a significant reduction in the final waste volume to less than half of the initial Parsons' estimate. The final volume factor decrease in this case is 0.75 , while more recent data suggest that this could go as low as 0.5 . The treatment cost for this scenario is $\$ 800$ per cuyd with disposal costs of $\$ 200$ per cuyd for a total of $\$ 1000$ per cuyd. This is the lowest total cost analyzed of the five scenarios.

Columns C, D, and E show the total life cycle cost estimates for cementation. Parsons' initial estimate for cementation only considered the sludges, therefore no soil washing was considered. However, soil washing was factored into column $\mathrm{E}$ to provide a better comparison for the total 
treatment picture which should include both the sludges and associated soils in the surrounding area and berms. Only then do we have a fair comparison to the scenario considered in the two vitrification options.

Column $\mathrm{C}$ is the estimate from Parsons, which assumes a volume factor increase of 3.17 due to the volume of cement and fly ash required to generate a 500 psi grout and to meet the minimum leach requirements for the uranium and heavy metals. Even so, this still does not sufficiently contain the technetium (Tc 99) which is a major problem for cement based systems.

Containerization is added to serve as a mold and for ease of handling which adds significantly to the costs. This cost is figured into the Operations Total under the Treatment costs. The treatment costs are estimated at $\$ 1200$ per cuyd with disposal costs of $\$ 800$ per cuyd for a total cost of $\$ 2000$ per cuyd.

Column D is the first adjustment which reflects an increase in volume factor for the cement, and also that due to the container itself which was not factored into the initial estimate. This resulted in slight increases in both the treatment and disposal costs for a total cost of $\$ 2300$ per cuyd. Column $E$ reflects the total adjustments to cementation which includes treatment and disposal of the soil fractions for closer comparison to the vitrification scenario. This increases the total treatment costs due to the larger volume of material to be treated, while the cost per cuyd remain roughly constant at $\$ 2300$. However, on a unit basis the treatment costs decrease slightly while the disposal costs rise slightly.

The last two rows of the table titled "DELTA VITRIFICATION (\$)" and "DELTA (\%)" compare each scenario to the low cost vitrification scenario of Column B showing the overall cost savings in $\$$ and the percentage respectively. Columns B and $E$ are believed to represent the most realistic scenarios and comparable estimates for vitrification versus cementation respectively. Roughly $\$ 720 \mathrm{M}$ savings using the MAWS approach, or $56 \%$ over a comparable cementation scenario are projected based on these analyses.

When these numbers are rounded to better reflect the $+30 /-50 \%$ confidence in the estimates, the range for the combined cementation treatment and disposal costs is from $\$ 1500$ to $\$ 3000$ per cubic yard. The cost range for vitrification using MAWS is from $\$ 700$ to $\$ 1300$ per cubic yard of waste. Comparing the worst case using vitrification to the best case using cementation there is a cost savings of $\$ 200$ per cubic yard, which when applied to the 557,000 cubic yards of sludges and soil to be treated, results in a conservative cost savings of $\$ 100 \mathrm{M}$. On the other hand, comparing the best case vitrification scenario to the worst case cementation scenario could result in cost savings of as much as $\$ 1200 \mathrm{M}$. In either case, the cost savings are significant and favor vitrification which is also an environmentally better treatment approach.

\section{PERSPECTIVES}

- The largest cost delta comes from the disposal costs, which are driven by the large bulk associated with cementation. At $\$ 258 /$ cuyd for near site disposal, this amounts to $\$ 537 \mathrm{M}$ for cementation (of $2,080,600$ cuyd) versus $\$ 108 \mathrm{M}$ for vitrification (of 417,000 cuyd). 
- The next largest cost delta comes from the steel boxes needed for cementation storage. Assuming the vitrified glass gems need no further containerization, the cost difference is $\$ 226 \mathrm{M}$. This cost is included on the "Operations" line of the attached matrix work sheet. One may want to also include a containerization cost for the gems, if at some future time it is necessary to retrieve them from burial/storage, however due to the reduced volume of glass waste this cost would be only about $\$ 50 \mathrm{M}$ at most.

- Although costs for engineering, design, and construction of facilities for both cementation and vitrification are included, these costs account for only $\$ 9 \mathrm{M}$ difference.

- Costs of material handling account for most of the remaining differential. The glass melters are generally less labor intensive than the cementation operations.

- Total waste to be treated includes 467,000 cuyds of OU-1 wastes found in 6 pits, a burn pit, and clear-well plus 90,000 cuyds of soil which is net after soil washing of surrounding contaminated soil for a total of 557,000 cuyds. Soil washing could be fine tuned to generate less volume, but this volume is needed to generate a suitable glass during vitrification.

- The cement scenario $\$ 970 /$ cuyd unit disposal cost comes from $\$ 258$ (basis/cuyd) x 3.75 (volume factor for cementation) $=967.5$, rounded up to $\$ 970$. The vitrification scenario disposal cost is similarly affected by the volume factor reduction of 0.75 resulting in a final unit cost of $\$ 195 /$ cuyd of waste treated.

- A vitrified waste form may potentially be delistable, which could result in significant additional savings. Initial estimates for far-site disposal were $\$ 1620 /$ cuyd listed versus \$216/cuyd delisted, i.e. simple low-level waste.

\section{APPLICABILITY BEYOND FERNALD OU-1}

Within Fernald there are other operable units having wastes that could potentially be treated with the MAWS approach. To date about 25,000 cubic yards of such wastes have been identified including such materials as transite, asbestos, neutralization sludges, and $\mathrm{K} 65$ silo wastes. Beyond Fernald, discussions have been initiated with Oak Ridge, where another 35,000 cubic yards of materials have been identified such as pond waste, neutralization sludges, soils, and ashes. Also, discussions have occurred with Hanford in regards to the large quantities of tank wastes. If a low-level waste stream can be separated from this material, then a MAWS approach would be applicable to treat this material in combination with contaminated soils. At Savannah River a recent award was made to GTS Duratek (the MAWS contractor) for a vitrification system to treat 600,000 gallon of $\mathrm{M}$-area sludges. This won out over cementation and a polyethylene encapsulation treatment scenario. This vitrification process will achieve a relatively high waste loading typically associated with the MAWS approach.

These are only the beginning efforts to identify wastes that might be treated in a similar cost effective way, therefore the full potential of using this approach is yet to be determined. The cost savings using a MAWS vitrification approach could be significant. 


\section{REFERENCES}

Working level notes from DOE Fernald and WEMCO (Jan. 1993).

Private communications with Fernald, Oak Ridge, and Hanford field personnel.

Private communication with GTS Duratek. 


\section{Fernald OU-1 Waste Treatment Scenario Analysis}

\begin{tabular}{|c|c|c|c|c|c|}
\hline WASTE BASES & $\begin{array}{c}\text { A } \\
\text { Vitrify } \\
\text { Parsons }\end{array}$ & $\begin{array}{c}\text { B } \\
\text { Vitrify } \\
\text { Adjusted }\end{array}$ & $\begin{array}{c}\text { C } \\
\text { Cement } \\
\text { Parsons }\end{array}$ & $\begin{array}{c}\text { D } \\
\text { Cement } \\
\text { Adjusted }\end{array}$ & $\begin{array}{c}\mathbf{E} \\
\text { Cement } \\
\text { Adjusted+ }\end{array}$ \\
\hline Pit Wastes (cuyd) & 467000 & 467000 & 467000 & 467000 & 467000 \\
\hline Soil/sand (cuyd) & 180000 & 90000 & 0 & 0 & 90000 \\
\hline Volume Factor & 1.44 & 0.75 & 3.17 & 3.61 & 3.74 \\
\hline Treated Waste (cuyd) & 934000 & 417000 & 1480000 & 1687200 & 2080600 \\
\hline Form & $\begin{array}{r}\text { Frit } \\
50 \% \text { void }\end{array}$ & $\begin{array}{r}\text { Gems } \\
25 \% \text { void }\end{array}$ & $\begin{array}{r}\text { Grout } \\
500 \mathrm{psi}\end{array}$ & $\begin{array}{r}\text { Grout } \\
500 \text { psi }\end{array}$ & $\begin{array}{r}\text { Grout } \\
500 \text { psi }\end{array}$ \\
\hline Near-site Disp. Cost Rate (\$/cuyd) & 258.00 & 258.00 & 258.00 & 258.00 & 258.00 \\
\hline B25 Containers@ $\$ 500$ each & yes, & no & yes & yes & yes \\
\hline \multicolumn{6}{|c|}{ COST CALCULATIONS ( $\$$ x 1000) } \\
\hline Engineering \& Design (\$) & 10900 & 10000 & 8200 & 9170 & 10560 \\
\hline Site Prep \& Security & 6787 & 6188 & 4453 & 4453 & 5126 \\
\hline Waste Removal \& Transfer & 41218 & 27213 & 27213 & 27213 & 31323 \\
\hline Treatment System \& Facility & 174497 & 107754 & 85598 & 99803 & 114877 \\
\hline Utilities \& Support Facilities & 19000 & 11600 & 5195 & 5610 & 6458 \\
\hline Treatment Transfer System & 987 & 600 & 3340 & 3607 & 4151 \\
\hline Construction Total (\$) & 242489 & 153355 & 125799 & 140686 & 161935 \\
\hline Processing Operations & 268300 & 189000 & 161100 & 183654 & 210881 \\
\hline Material Handling \& Transport & 17100 & 4275 & 20100 & 22914 & 26293 \\
\hline Containers & 96200 & 0 & 172600 & 196764 & 225973 \\
\hline Onerations Total (\$) & 381600 & 193275 & 353800 & 403332 & 463147 \\
\hline Maintenance (\$) & 81900 & 61500 & 46200 & 52668 & 67678 \\
\hline D\&D, Greenfielding, Monitoring (\$) & 43700 & 32800 & 28400 & 32376 & 37184 \\
\hline TOTAL TREATMENT (\$) & 760589 & 450930 & 562399 & 638232 & 740504 \\
\hline TOTAL DISPOSAL (\$) & 240972 & 107586 & 381840 & 435298 & 536795 \\
\hline TOTAL COST $(\$)$ & 1001561 & 558516 & 944239 & 1073530 & 1277299 \\
\hline Waste Treatment Cost ( $\$ /$ cuyd) & 1175.56 & 809.57 & 1204.28 & 1366.66 & 1329.45 \\
\hline Waste Disposal Cost (\$/cuyd) & 372.45 & 193.15 & 817.64 & 932.11 & 963.72 \\
\hline Waste Treat+Dispose Cost (\$/cuyd) & 1548.01 & 1002.72 & 2021.93 & 2298.78 & 2293.18 \\
\hline DELTA VITRIFICATION (\$) & $\begin{array}{r}443045 \\
4424\end{array}$ & $\begin{aligned} 0 \\
0\end{aligned}$ & $\begin{array}{r}385723 \\
4085\end{array}$ & $\begin{array}{r}515014 \\
4797\end{array}$ & $\begin{array}{r}718783 \\
5627\end{array}$ \\
\hline & 44.24 & 0.00 & 40.85 & 47.91 & 56.27 \\
\hline
\end{tabular}



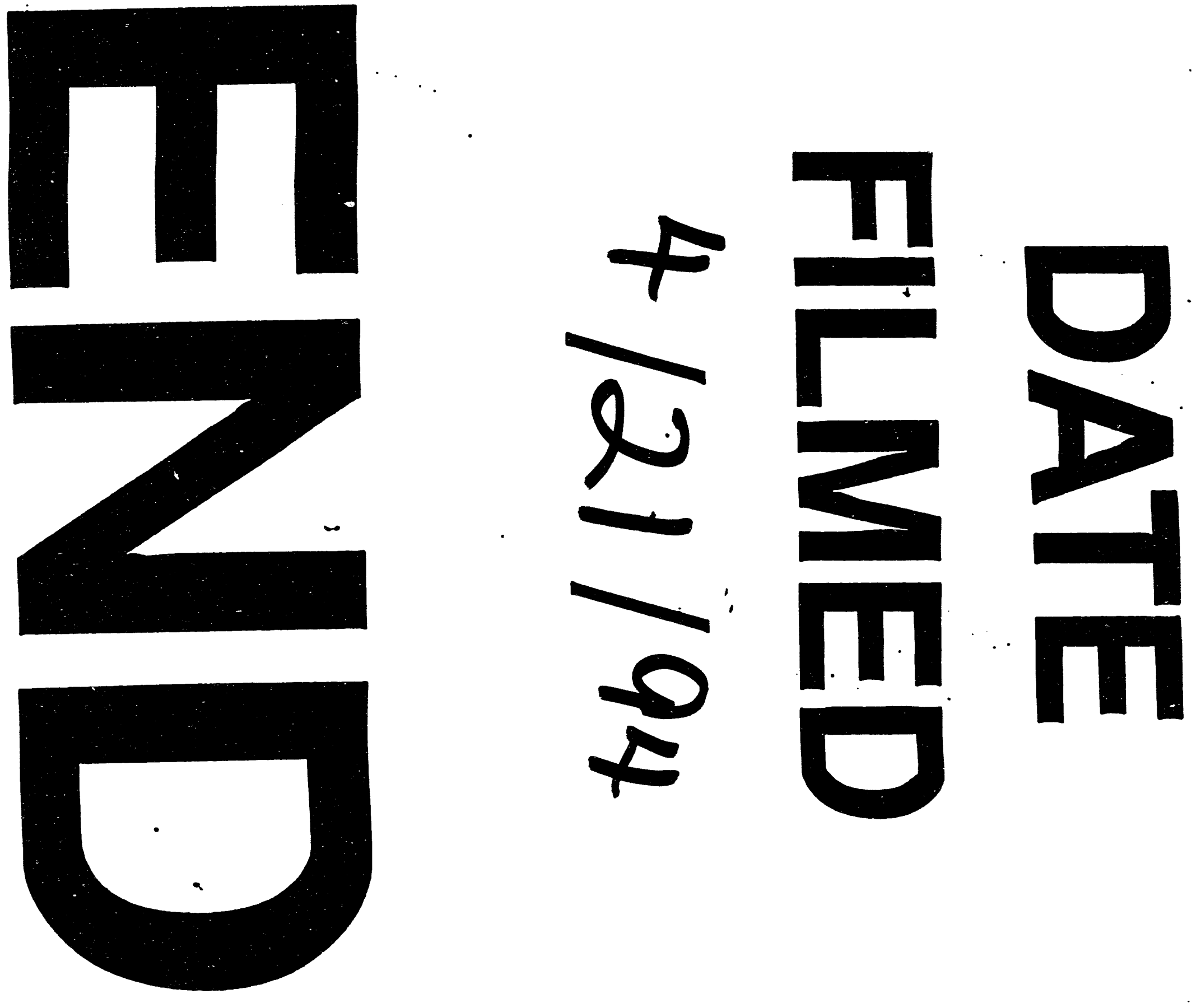
